\title{
Elephantidae phylogeny: morphological versus molecular results
}

\author{
Jeheskel SHOSHANI*, Edward M. GOLENBERG and Hong YANG***
}

Shoshanj J., Golenberg E. M. and Yang H. 1998. Elephantidae phylogeny: morphological versus molecular results. [In: Ecological genetics in mammals III. G. B. Hartl and J. Markowski, edsJ. Acta Therinlogica, Suppl. 5: 89-122.

Traditionally, morphologically based phylogenetic relationships within the family Elephantidae (mostly Loxodonta, Elephas, and Mammuthus) depicted Elephas and Mammuthus as closely related taxa with Loxodonta as a sister-group to this clade. Until recently, molecular studies were unable to resolve relationships among the woolly mammoth (Mammuthus), Asian (Elephas), and African (Loxodonta) elephants, or indicated a phenetic pairing of Loxodonta and Mammuthus with Elephas as a sister-group to this grade. In this study we provide further morpholngical evidence for the traditional hypothesis and data from aligned DNA sequences of the mitochondrial gene cytochrome $b$ in support of the monophyletic Mammuthus-Elephas clade. In both data sets, morphological and molecular, the extinct American mastodon (Mammut) was employed as an outgroup. The molecular results demonstrate the importance of using a closely related taxon as an outgroup for resolving phylogenies of highly derived species. Tests on the importance of the numbers of outgroups and which outgroup may be better for testing phylogenetic relationships reveal that the closer the outgroup to the ingroup, the more corroborative the results will be. Evolutionary rates calculated from the morphological characters indicate that, among the three genera studied, Loxodonta is the slowest evolving taxon, followed by Elephas, and Mammuthus. DNA sequences indicate similar rate differences among the three taxa. Morphological data also corroborate the classical hypothesis that the family Stegodontidae is monophyletic and its members (Stegolophodon and Stegodon) do not group within Elephantidae. A comparison among mammoths reveals that many of the skull characters are interlinked and may be considered as one, or as a suite of characters, eg antero-posterior compression of skull. An important trend has been observed - the most primitive mammoths had fewer numbers of plates per given tooth and lower lamellar frequencies. A simplified possible mammoth ancestry and radiation is provided.

Department of Biological Sciences, Wayne State University, Detroit, Michigan 48202 USA (JS, EMG, HY); Cranbrook Institute of Seience, Bloomfield Hills, Michigan 48304 USA (JS); Department of Human Genetics, Medical Science II M4708, University of Michigan Medical School, Ann Arbor, Michigan 48109-0618 USA (HY)

Key words: Elephantidae, phylogeny, morphology, molecules, outgroups

\section{Introduction}

Taxonomists find it tantalizing to resolve questions related to phylogenetic relationships, especially if these are obscured by the fossil record, making such

*Present address: Department of Biology, University of Asmara, P.O. Box 1220, Asmara, Eritrea ** Present address: Department of Science and Technology, Bryant College, Smithfield, Rode Island, 02917 USA 
studies scholarly challenges, a paleontological and neontological game. Early workers (eg Blumenbach, 1779) employed the generic name Elephas for mammoths and living Asian elephants, a format also followed by some more recent workers (eg Ezra and Cook 1959, Krause 1978). This is not surprising since it is very difficult to distinguish between many closely related taxa the closer one gets to their splitting time in the geological record. For example, earliest elephantid genera are phenotypically extremely similar to one another, and this caused confusion in early stages of research until better diagnostic characters were made available (Maglio 1973, Coppens et al. 1978). Dispute over the generic validity of Loxodonta and Elephas dates back to Cuvier (1825), who regarded them as distinct taxa "differing from each other as much as Canis from Hyaena, or Lagomys from Lepus". Based on external ear morphology, however, Lydekker (1907, 1916), considered Loxodonta a subgenus of Elephas which he designated as Elephas (Loxodonta) africana. If one accepts the earlier hypothesis that the extinct mammoth, Mammuthus, should be synonymized with Elephas (Blumenbach, 1779), then Elephas would span all three genera. Recent workers (eg Aguirre 1969, Maglio 1973, Coppens et al. 1978, Jones 1984, Tassy and Shoshani 1988) consider these three genera distinct because of unique characters, especially of the skull and teeth. Shoshani et al. (1985b) analyzed 251 characters (a part of Shoshani's 1986 characters) and provided cladistic evidence for the uniqueness of the three separate genera.

Of course, it would be impossible to study phylogenetic relationships with only two living species, the African elephant (Loxodonta africana), and the Asian elephant (Elephas maximus). Fortunately, well-preserved carcasses of woolly mammoths (Mammuthus primigenius), discovered in the Arctic, have provided a unique opportunity to study their soft tissues morphologically and their genes by molecular methods. Together with other extinct proboscideans, Mammuthus and the American mastodon (Mammut americanum) provide the framework for character evaluation. The richness of proboscidean fossils has facilitated our search for overall evolutionary pathways within the Proboscidea.

Detailed osteological (dentition included) studies of elephantid taxa provided evidence to suggest that among members of the subfamily Elephantinae, Loxodonta is the most primitive genus (eg Aguirre 1969, Maglio 1973). These results appeared unchallenged and were accepted as the "traditional hypothesis", even though not all morphological studies confirmed these findings. For example, Valente (1983), employing hair structure, was unable to corroborate these results; he reported on an unresolved trichotomy among Loxodonta, Elephas, and Mammuthus. Shoshani et al. $(1985 \mathrm{a}, \mathrm{b})$ reported on polytomies based on soft tissue or bone prote:ns and collagen, although Shoshani et al. (1985b) reported on additional osteological evidence that supports the traditional hypothesis. A challenge to this hypothesis came from DNA data on modern and extinct taxa. Hagelberg et al. (1994) studied DNA sequences of cytochrome $b$ gene of Loxodonta africana, Elephas meximus, and Mammuthus primigenius and using dolphin and rhinoceros as outzroups, 
suggested "... that Mammuthus and Loxodonta could be sister-taxa in a monophyletic clade". Höss et al. (1994) also studied DNA sequences of these elephantid species (their outgroups were cow and horse) and concluded that the four woolly mammoths they studied "... differ from each other by $0-5$ substitutions whereas the Indian and African elephants, representing two genera, differ by only two substitutions". Such an extensive polymorphism among individual mammoths, as opposed to smaller differences between genera, raises a caution flag and requires additional investigation of the same samples and of the data generated by Höss et al. (1994). A close examination of Hagelberg et al.'s (1994, p. 334) DNA sequences reveals a two codon deletion. As these codons are present in all other mammals, we assume that the sequence differences may be due to a typographical error. Further, their results are in contrast to anatomical (Shoshani et al. 1985b) and molecular (Yang et al. 1996) data, and are inconsistent with the classical morphologically based hypothesis. We believe these contradicting findings of Hagelberg et al.'s (1994) may have resulted from using distant outgroups (a cetacean and a perissodactyl). Indeed, Ulrich Joger (personal communication, 28. June 1996) reported to J. Shoshani "... contrary to our previous data and to the results of Hagelberg, Thomas, and Lister, our extended cytochrome $b$ fragment (which is different from yours) has a large number of shared derived characters of both Mammuthus and Elephas". When a proboscidean taxon such as the American mastodon (Mammut americanum) is used to study sequences of cytochrome $b$ mitochondrial DNA (mtDNA) sequences within Elephantinae, a corroboration of the traditional hypothesis was achieved (Yang et al. 1996). Most recently, Ozawa et al. (1997) confirmed the findings of Yang et al. (1996) without the inclusion of Mammut americanum in their molecular study but with a larger cytochrome $b$ mtDNA segment.

A more recent controversy concerns whether the stegodontids, Stegolophodon and Stegodon, should be grouped within the Elephantidae or should be considered as a separate family, the Stegodontidae. Traditionally, Stegolophodon and Stegodon have been an inseparable part of the family Stegodontidae (eg Osborn 1942, Coppens et al. 1978, Saegusa 1996, Shoshani 1996). Kalb et al. (1996), however, reported that Stegodontidae is paraphyletic (or polyphyletic, depending on the relative extent of the group examined) and argued that both Stegolophodon and Stegodon should be classified within the family Elephantidae, and thus, abolishing the family Stegodontidae.

In this paper we provide expanded data of morphological (mostly osteological, including dentition) characters to test further the relationship among Loxodonta, Elephas, and Mammuthus. In addition, we test the phylogenetic position of Stegolophodon and Stegodon within Proboscidea. To strengthen the methods of testing, other elephantid genera are included in the analysis. We also increased the number of outgroups to include gomphotheres (eg Gomphotherium) in addition to Mammut. This expanded morphological data base provides stronger evidence and further support for the traditional hypothesis of relationships within elephantid 
genera. This study addresses the following specific questions: (1) which taxa should be included in Elephantidae, (2) do members of the subfamily Elephantinae have a resolved branching arrangement, (3) how significant is DNA isolated from an extinct taxon in testing phylogenetic hypotheses, (4) what are the evolutionary rates among elephantid taxa. An additional related question is the validity of various elephantid genera and species that had to be considered in the early stages of this study because synonymies affect the choice of taxa for analysis. The choice of characters and methods of analysis (see Material and methods) are also important considerations.

\section{Material and methods}

\section{Morphological characters examined}

Characters studied in this paper include 95 skeletal as well as dental features, taken from the matrices of Shoshani $(1986,1996)$, Tassy and Darlu (1986), Kalb et al. (1996), Saegusa (1996), and Tassy (1996) and summarized in Appendix 1. Of these 95 characters, 72 are binary (only " 0 " and " 1 " codes) and 23 are multistate characters (codes $0,1,2,3,4$, and 5 used). Missing data were coded as "?". Note that only 66 of 123 characters of Shoshani (1996) are used; characters that are monomorphic in all taxa within this study were deleted (see details below). In addition, we included 12 of the 40 characters of Tassy and Darlu (1986) and 16 of the 34 characters of Kalb et al. (1996) to test their hypotheses (Appendix 1).

Our combined data matrix was constructed after comparing the characters of Shoshani (1996) to those of Tassy and Darlu (1986) and Kalb et al. (1996). Duplications of characters were deleted after verifying that there were no conflicts in the coding of these characters. Conflicts were edited based on re-examination of the characters for the specific taxa in question. For example, character 7 of Kalb et al. (1996) was not included in our combined set because it is identical to character 9 of Shoshani (1996). Similarly, characters 8 and 9 (also 10, 11, and 12) of Kalb et al. (1996) were not includer because both (or the three) are part of our character nos. 7 and 94 , respectively (note: when analyzing the data with unordered option, splitting one multistate character into two or three binary characters gives them more weight than if they were combined into one). Also, character 24 of Kalb et al. (1996) is subsumed by their character nos. 32-34. Character nos. 32-34 of Kalb et al. (1996), were better defined than those of Shoshani (1996, eg nos. 43 and 50), and thus we retained those of Kalb et al. (1996) instead of nos. 43 and 50. After careful comparison of Kalb et al.'s (1996) data matrix to that of Shoshani (1996), we deleted 18 of their characters (12 duplicates, 2 from condensing, 3 not applicable - because we did not employ four of their genera, or because a character is autapomorphic, and 1 because a character was vaguel. Similarly, 28 of 40 of Tassy and Darlu (1986) were deleted, bringing the total combined set in this analysis to 95 characters (16 of Kalb et al, 12 of Tassy and Darlu, 66 of Shoshani, and 1 new characters as given in Appendix 1, and tabulated in Appendix 2).

\section{Taxa and specimens studied by morphological methods}

The choice of these taxa was dictated, in part, by the taxa studied by the authors whose hypotheses we are testing. For this reason, a total of 14 genera/taxa is included in this study. Of these, eight are ingroup or terminal taxa (Mammuthus, Elephas, Loxodonta, Primelephas, Stegodibelodon, Stegotetrabelodon, Stegodon, and Stegolophodon) and the remaining seven are outgroups (Paratetralophodon, Anancus, Tetralophodon, Gomphotherium, Mammut, and Phiomia) as given in Appendix 2. The most plesiomorphic outgroup employed is Phiomia. In earlier studies (eg Shoshani et al. 1985b) Mammat was used as an outgroup; Phiomia, Gomphotheritum and other gomphotheres are included 
here to test a broader scope of hypotheses (relationships within Elephantidae and Stegodontidae), and to test the branching pattern of Kalb et al. (1996), who also used Phiomia as their outgroup. The character matrix of Kalb et al. (1996) for Phiomia was coded, however, with " 0 " (the primitive condition? for all the characters, whereas we used actual data for the characters we analyzed. Also note that the inclusion of Phiomia as an outgroup does not negate the function of Mammut as an outgroup taxon. On the contrary, it strengthens the testing because, with more than one outgroup, the polarities (direction of evolution) and transformation (changes of character states of one character) of characters for the ingroup - Elephantidae and Stegodontidae - are better defined. For simplicity,

Table 1. A non-ranked simplified classification of 14 proboscidean genera employed in this study (cf Fig. 1A and Appendix 2; partly after Shoshani and Tassy 1996, and after McKenna et al. 1997).

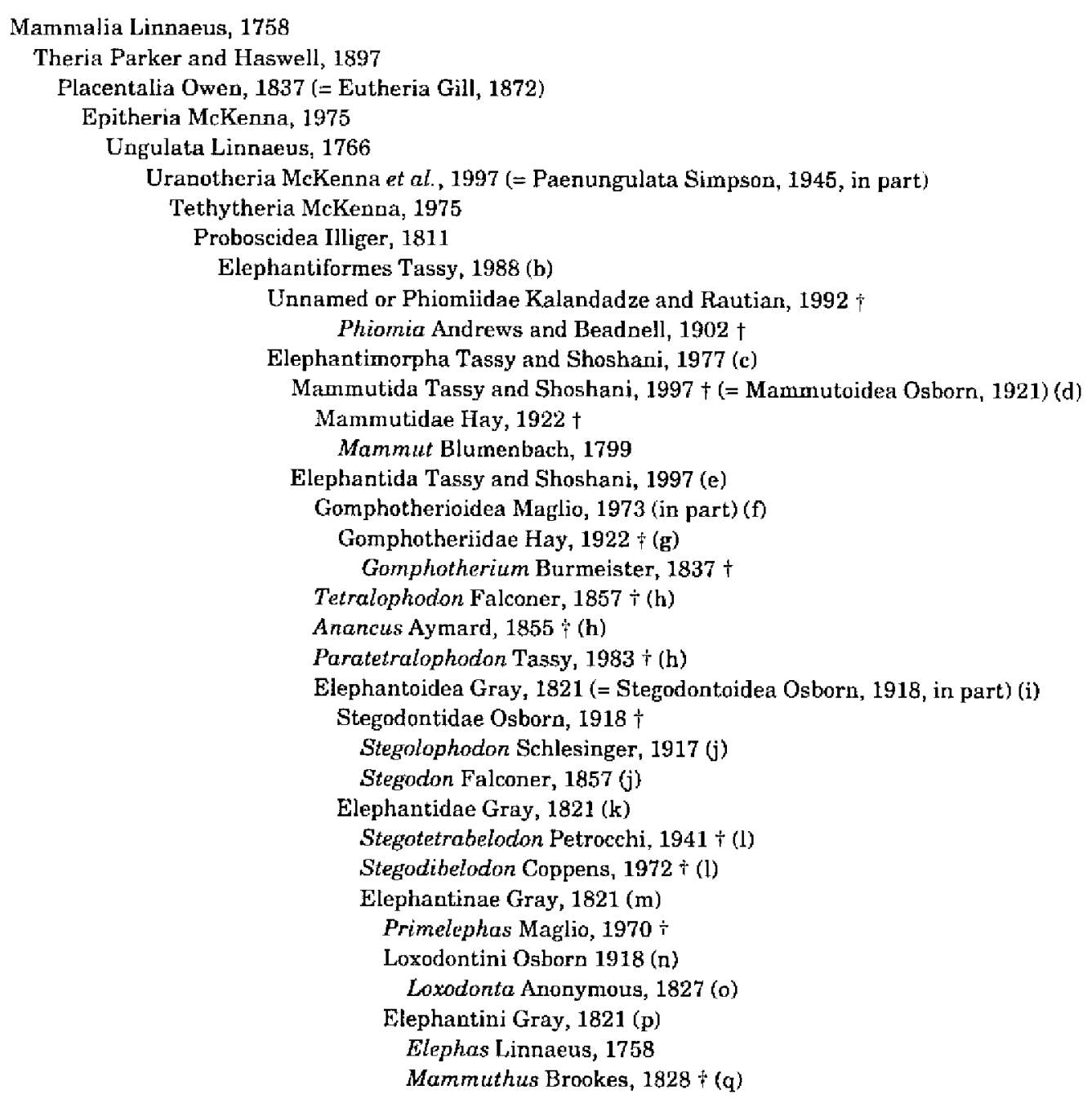


(a) Arrangements of genera, families, or higher categories in this classification (from top to bottom), correspond to the general sequence of the branching pattern from !eft to right in Fig. 1A. It is helieved that comprehensive classification of proboscidean terminal taxa (about 40 genera) will not alter the general scheme presented here. Most references to authorships are not included in this paper unless they are mentioned elsewhere in this article; they may be found in Osborn (1936, 1942), Shoshani and Tassy (1996), and McKenna et al. (1997). (b) This entry (Elephantiformes) corresponds to node A in Fig. 1A. (c) This clade (tentatively named "Elephantimorpha", corresponds to node B in Fig. 1A) may be given a suborder (eg Osborn 1921 p. 2) or infraorder rank. Tassy (1988, p. 46) named members of this clade (not in the same arrangement) "Elephantoidea", a superfamily (as used by Osborn 1942, p. 1582), in accordance with the International Commission for Zoological Nomenclature (ICZN) Recommendation 29a (since the classification is based on extant species; for the same reason we use "subfamily Elephantinae" and "family Elephantidae", and all receive the same authorship "Gray 1821"). P. Tassy and J. Shoshani (in a meeting in Paris, France March 1997) agreed to restrict the suffix of "-oidea" to a superfamily rank. For this reason, the name Mammutida is used instead of Mammutoidea, and Elephantida as a sister taxon. (d) Tentatively called "Mammutida", this clade may be given a suborder (eg Osborn 1921, p. 2, Maglio 1973, p. 15, Coppens et al. 1978, p. 339) or infraorder rank. If superfamily rank is given, then the authorship should be Hay 1922, following ICZN Recommendation 29a. Note that the content of this clade as shown here is very different from that of Maglio (1973) and Coppens et al. (1978) who grouped Stegodontidae and Mammutidae in Mammutoidea. (e) This clade (tentatively called "Elephantida") corresponds to node $\mathrm{C}$ in Fig. $1 \mathrm{~A}$ and may be of a suborder or infraorder rank (f) Maglio (1973) and Coppens et al. (1978, p. 339) employed the term "Gomphotherioidea" as a suborder of Proboscidea to embrace Gomphotheriidae and Elephantidae. Stegodontidae, according to these authors, was included in the suborder Mammutoidea. In this study, Stegodontidae is a sister group to Elephantidae. (g) This monophyletic family (Gomphotherijdae) may include, in addition to Gompiotherium, other trilophodont grade gomphotheres. Positions of the tetralophodont grade gomphotheres are shown in Fig. 1A and noted below, note (h). (h) These three tetralophodont gomphothere taxa (Tetralophodon, Anancus, Paratetralophodon - probably form a grade, or a paraphyletic group; cf Shoshani and Tassy 1996), are included here to accommodate part of the data set of Tassy and Darlu (1986) and Kalb et al. (1996). (i) This entry ("Elephantoidea") corresponds to node G in Fig. 1A. (j) Kalb et al. (1996) proposed that Stegolophodon and Stegodon should be classified within the family Elephantidae, and thus abolishing the family Stegodontidae. (k) This entry ("Elephantidae") corresponds to node $\mathrm{H} n \mathrm{Fig}$. $1 \mathrm{~A}$. According to Maglio (1973) and Coppens et al. (1978), Elephantidae includes six genera with 25 species as follows: Stegotetrabelodon (with 2 species), Stegodibelodon (with 1), Primelephas (with 1), Loxodonta (with 3), Elephas (with 11) and Mammuthus (with 7). In the summary of Shoshani and Trssy (1996, incorporating the ideas of Webb and Dudley 1995) the total of elephantid species varies between 39 and 43. Another possible valid species is Loxodonta cyclotis (Groves et al. 1993). Shoshani (1993) however, considered "Loxodonta cyclotis" a plesiomorphic sister group to Loxodonta africana, and sugzested the use of two subspecies - ie Loxodonta africana africana and $L$, a. cyclotis - until additioncl evidence becomes available. If one accepts Kalb et al. (1996) hypothesis that Stegodontidae (Stegolopiodon and Stegodon) be included in Elephantidae, then the total number of species would rise and vay from 42 to 77. (1) Maglio (1973) and Coppens et al. (1978) proposed to classify Stegotetrabelodon and Stegodibelodon in the subfamily Stegotetrabelodontinae. 'This hypothesis does not seem to be corroborated by recent workers (eg Tassy and Darlu 1986, Tassy 1996, Kalb et al. 1996, Shoshani 1996). (m) This entry ("Elephantinae") corresponds to node K in Fig. 1A. (n) Following ICZN, Articles 62-65, the iuthorship for Loxodontini should be Osborn 1918 (see page 1191 in Osborn 1945), since he gave the name "Loxodontinae", one of the family group names. An error appears in Shoshani (1998, p. 482) - the authorship for Loxodontini should be Osborn 1918, not Kalandadze and Rautian 1992. (o) The author is "Anonymous 1827", not "F. Cuvier 1825"; details in Appendix C of Shoshani and Tassy 1996). (p) This entry (Elephantini) corresponds to node L in Fig. 1A. (q) The author is "Brookes 1828", nd "Burnett 1830"; details in Appendix A of Shoshani and Tassy (1996). 
Table 2. Hypotheses testing among proboscidean taxa.

\begin{tabular}{|c|c|c|c|}
\hline $\begin{array}{l}\text { Test } \\
\text { number }\end{array}$ & Hypotheses tested* & $\begin{array}{c}\text { Tree } \\
\text { length }\end{array}$ & $\begin{array}{l}\text { Change } \\
\text { from Test } 0\end{array}$ \\
\hline 0 & The most parsimonious tree; Fig. IA (1) & 137 & - \\
\hline 1 & Stegodibelodon joined with Stegotetrabelodon (2) & 140 & 3 \\
\hline 2 & Stegodon in front of Stegotetrabelodon (3) & 139 & 2 \\
\hline 3 & Stegodon joined with Stegotetrabelodon (3) & 141 & 4 \\
\hline 4 & Stegodon in front of Stegodibelodon (3) & 140 & 3 \\
\hline 5 & Stegodon joined with Stegodibelodon (3) & 142 & 5 \\
\hline 6 & Stegodon in front of Primelephas (3) & 141 & 4 \\
\hline 7 & Stegodon joined with Primelephas (3) & 144 & 7 \\
\hline 8 & Stegodon in front of Loxodonta (4) & 143 & 6 \\
\hline 9 & Stegodon joined with Loxodonta (4) & 147 & 10 \\
\hline 10 & Elephas joined with Loxodonta (4) & 142 & 5 \\
\hline 11 & Mammuthus joined with Loxodonta (4) & 142 & 5 \\
\hline 12 & $\begin{array}{l}\text { As in test no. } 6 \text {, but also exchange the positions of Tetralophodon } \\
\text { with Anancus (5) }\end{array}$ & 145 & 8 \\
\hline 13 & Tetralophodon and Anancus exchange positions (6) & 143 & 6 \\
\hline 14 & Tetralophodon and Anancus joined together (6) & 144 & 7 \\
\hline 15 & Tetralophodon and Paratetralophodon exchange positions (6) & 146 & 9 \\
\hline 16 & Tetralophodon and Paratetralophodon joined together (6) & 145 & 8 \\
\hline 17 & Anancus and Paratetralophodon exchange positions (6) & 139 & 2 \\
\hline 18 & Anancus and Paratetralophodon joined together (6) & 139 & 2 \\
\hline 19 & Stegodontidae in front of Gomphotherium (7) & 159 & 22 \\
\hline 20 & Stegodontidae joined with Gomphotherium (7) & 159 & 22 \\
\hline 21 & Stegodontidae joined with Mammut (8) & 165 & 28 \\
\hline 22 & Gomphotherium joined with Phiomia (9) & 144 & 9 \\
\hline 23 & All 4 gomphotheres separately joined with Phiomia as outgroup (9) & 159 & 22 \\
\hline 24 & All 4 gomphotheres together joined with Phiomia as outgroup (9) & 174 & 37 \\
\hline 25 & All 4 gomphotheres joined Phiomia, Mammut is outgroup (10) & 174 & 37 \\
\hline
\end{tabular}

* The 25 tests presented in this table are a sample of tests conducted "manually" with MacClade program. All test conducted with the characters "unordered", ie, in all characters it costs only one step in the sequence of transformation from one multistate character to another. The numbers in the third column are the length of the cladogram (or the minimum number of evolutionary steps required for a given tree topology) obtained when running PAUP, and the numbers of changes (fourth column) are the differences between this tree topology and one of the most parsimonious trees, Test no. 0 . (1) Each hypothesis testing was performed on the original tree; in other words, after one test was completed, the branching arrangement was returned to its original topology (as shown in Fig. 1A) before conducting the next test. Other details are given under Material and methods. (2) Hypothesis after Maglio (1973) and Coppens et al. (1978) who proposed to classify Stegodibelodon and Stegotetrabelodon in the subfamily Stegotetrabelodontinae, family Elephantidae. (3) A part of a hypothesis proposed by Kalb et al. (1996), or towards understanding or testing this hypothesis. Kalb et al (1996) proposed to abolish the family Stegodontidae because it is paraphyletic (or polyphyletic, depending on the relative extent of the group examined) and both Stegolophodon and Stegodon should be classified within the family Elephantidae. In test no. 2, Stegodon as a sister-group of Elephantidae (content as in Maglio 1973 and Coppens et al. 1978). (4) Test conducted to learn the range in step changes when Stegodon, Elephas, and Mammuthus are joined to Loxodonta. (5). This branching pattern is similar to that proposed by Kalb et al. (1996, p. 
106), except that here we have two additional genera, Gomphotherium and Mammut. (6) The purpose of these tests is to further examine the relationships among gomphothere taxa and to further elucidate their paraphyletic ("the wastebasket hypothesis") or monophyletic status (cf Shoshani 1996, Tassy 1996). (7) Test conducted to understand better the plasticity of the characters used with reference to notes nos 4 5 above. (8) A hypothesis suggested by Maglio (1973) and Tobien (1988). Note, however, that in this study Mammutidae is represented by Mammut, and could be the reason for the high (28 steps) difference, as opposed to 15 steps difference when tested with a denser character matrix (cf. Shoshani 1996, p. 171). (9) Towards understanding or testing the hypothesis that Phiomia was on the line of ancestry to gomphothere taxa (eg Tobien 1976, Coppens et al. 1978). (10) Exchanging the positions of Mammut and Phiomia on the most plesiomorphic branch on this cladogram (Fig. 1A) is a rhetorical test.

and to allow us to focus on the relationships between and among Stegodontidae and Elephantidae taxa, we present two sets of results, with and without all the gomphotheres.

This study reports results of analysis of specimens studied in the following museums: American Museum of Natural History (New York, USA); Beijing Natural History Museum (Beijing, Peoples Republic of China); Bristol University, Geology Museum (Bristol, England); Institute of Vertebrate Paleontology and Paleoanthropology (Beijing, Peoples Republic of China); Laboratoire de Paléontologie des Vertébrés et de Paléontologie Humaine, Université P. \& M. Curie (Paris, France); Muséum National d'Histoire Naturelle (Paris, France); Natural History Museum (London, England), formerly "British Museum (Natural History)". We also employed data - based on descriptions and illustrations - taken from selected literature reports. The validity of names, on the generic and species levels, used here (cf Table 1) necessitated synonymies of taxa and specimens for analysis (current senior synonyms we use are after Shoshani and Tassy 1996).

\section{Cladistic analysis of morphological data}

For the morphological data, computer analysis was conducted with Swofford's (1993) Phylogenetic analysis using parsimony (PAUP) version 3.1.1, and Maddison and Maddison's (1992) MacClade version 3.0. We tused the standard specifications for PAUP and MacClade analyses, except for the following (in PAUP): (1) Optimization was conducted using ACCTRAN (accelerated transformation) and DELTRAN (delayed transformation), MAXTREE was set to 100 and to "Automatically increase by $100^{\circ}$ intervals; (2) The "Heuristic" and "Exact Method" ("Branch and Bound") search options of PAUP were employed to identify the most parsimonious tree(s). In both searches characters were treated with equal weight and as unordered (for each multistate character, all transformations cost only one step), and the program allows reversals; (3) in the Heuristic search, all three options were tried (General, Stepwise addition, and Branch swapping); the Stepwise addition has four sub-options (As is, Closest, Simple, and Random) - all were performed, with 10 and 100 replications; (4) in all runs, the outgroups and the ingroups were not constrained, ie not specified. Results from PAUP with brief comments are given in Appendix 3 .

For the purpose of comparing molecular and morphological studies, we also tried different topologies of cladograms (manual branch swapping with MacClade; Table 2). In addition, we ran PAUP with only one ingroup (Stegodontidae and Elephantidae), but changed the number of the outgroups (Table 3 ).

\section{Molecular materials}

Ten specimens of Proboscidea were used for DNA extraction and analysis (seven extinct, two extant and one hybrid; details in Appendix 4). Fossil specimens ranged from about 46000 to 10200 years old. Note that Mammuthus (extinct), Elephas, and Loxodonto are classified in the family Elephantidae and Mammut (extinct) is placed in the family Mammutidae (Table 1). 
Table 3. Testing the importance of outgroups among proboscidean taxa. (1) The 10 tests* presented in this table are a sample of tests conducted "manually" with PAUP program (specifications in text). The first entry indicates the results as shown in Fig. 1A when all 14 taxa are included in the analysis. Subsequent tests were conducted such that some taxa were deleted from the matrix and the program was executed individually to obtain the results shown in the third and fourth columns. (2) The first number in this column refers either to a single tree/cladogram or two to three equally parsimonious trees as obtained from PAUP analysis, and the second number in parentheses refers to the tree length (TL). (3) Here the ingroups are defined as Stegodontidae and Elephantidae. Elephantidae always remained as a monophyletic taxan, thus the emphasis is on testing whether or not Stegodontidae would remain as a monophyletic taxon (cf Saegusa 1996, Shoshani 1996, Tassy 1996) or a paraphyletic (cf Kalb et al. 1996). An entry of "yes" means that the ingroup, specifically the Stegodontidae, is a monophyletic; "no" means that the Stegodon is joined with the stem of Elephantidae instead of with Stegolophodon. (4) Mammut + Stegodontidae (2 taxa) + Elephantidae (6 taxa), a total of 9 taxa. (5) This tree is the same as in Fig. 1A, and in the first entry to this table. (6) Tests from this entry to the end of this table were conducted by deleting individual taxa, rather than adding them as was done in the entries above.

\begin{tabular}{clcc}
$\begin{array}{c}\text { Number of } \\
\text { taxa tested }\end{array}$ & $\begin{array}{c}\text { Number of trees } \\
\text { and (TL) (2) }\end{array}$ & $\begin{array}{c}\text { Monophyly of } \\
\text { the ingroups (3) }\end{array}$ \\
\hline 14 & As in the most parsimonious tree; Fig. 1A (1) & $1(137)$ & yes \\
9 & Only Mammut, Stegodontidae and Elephantidae used (4) & $1(93)$ & yes \\
10 & As above with Phiomia added & $1(121)$ & yes \\
11 & As above with Gomphotherium added & $3(128)$ & no \\
12 & As above with Tetralophodon added & $2(132)$ & no \\
13 & As above with Anancus added & $1(136)$ & yes \\
14 & As above with Paratetralophodon added (5) & $1(137)$ & yes \\
13 & As in Fig. IA, but after deletion of Anancus (6) & $1(134)$ & yes \\
12 & As above, but after deletion of Tetralophodon & $1(131)$ & yes \\
11 & As above, but after deletion of Gomphotherium & $1(127)$ & yes \\
10 & As above, but after deletion of Mammut & $1(114)$ & yes \\
9 & As above, but after deletion of Phiomia & $1(62)$ & yes \\
\hline
\end{tabular}

* Note: there are 12 entries to this table but the first and the seventh are the same as in Fig. 1A, and thus not counted as "tests".

DNA extraction, amplification, and sequencing

Three different DNA isolation and purification approaches were used: traditional proteinase $\mathrm{K}$ (Hagelberg and Clegg 1991, Cooper 1994, Hardy et al. 1994), 2\% CTAB approach (Doyle and Doyle 1987, Golenberg 1994, Yang et al. 1997b), and glass bead approaches (Boom et al. 1990, Höss and Paabo 1993, Cano and Poinar 1993). Experiments were conducted in a plant molecular lab where no mammalian DNA (except human) was handled previously by following a blind test design (Yang et al. 1997a). Special care was taken to prevent contamination (eg equipment and reagents were dedicated solely for ancient DNA work). Whenever possible, disposable equipment was used, and reusable utensils were soaked in $0.5 \%$ sodium hypochlorite and then exposed to UV light for one hour prior to experimentation (for details, see Yang et al. 1997b).

Polymerase chain reaction (PCR) was performed using primers designed based on modern elephant cytochrome $b$ gene mtDNA sequences (Yang et al. 1996). Amplification of specimens Mammuthus (EL\#2) and Mammut (EL\#23) DNA were carried out using two-stage nested PCR with newly designed internal primers Elcytb65 (5' CTA CCC CAT CCA ACA TAT CAA CAT GAT 3') and Elcytb320R (5' CGG TAT TTC AAG TTT CCG AGT ATA GGT 3'); other details are given in Yang et 
al. (1996). The primary PCR product was used as a template without further purification in the second stage of the nested amplification. To monitor contamination, extraction and negative PCR controls from primary amplification were carried through the secondary PCR. DNA sequences were derived by direct dideoxy sequencing of PCR products (Barnard et al. 1994), and each sequence was read from both strands. To avoid or reduce bias in our study, the taxonomic identities of the samples were initially known only to the one author (JS) who was not performing the laboratory experiments; the other co-authors (EMG and HY) worked with numbers for the genetic testing, a type of blind testing design (Yang et al. 1997a). Correct identifications of Recent species and duplicates from ancient specimens were achieved when sequences determined in the laboratory were compared with previously published data (eg Irwin et al. 1991).

\section{Phylogenetic analyses on molecular data}

Phylogenetic analyses were performed using maximum parsimony with exhaustive search and equal character weighting (Swofford 1993) and by neighbor-joining analysis using two-parameter sequence distance estimates with a 10 to 1 transition to transversion ratio (Kumar et al. 1993 , Felsenstein 1993). As explained below, a ratio of expected transitions to transversions is required to generate distance estimates, and functions in estimating the number of multiple hits (mutations) occurring at a particular position or character. Thus, this ratio does not function as a character

Table 4. Evolutionary rates that occurred during geological time span for certain proboscidean taxa. Letters for nodes/clades, number of evolutionary changes (EC) along a branch, and divergence times are given in Fig. 1A. (1) For simplicity (and because of the close "splitting times"), individual rates for the time spans among nodes $\mathrm{C}$ through $\mathrm{G}$ and nodes $\mathrm{H}$ through $\mathrm{K}$ were omitted; they can be easily calculated from the data given on the cladogram (Fig. 1A). (2) Numbers before the slash $(/)$ refer to ECs for ACCTRAN option in PAUP, and the numbers following the slash are ECs for DELTRAN option in PAUP (cf caption to Fig. 1A and text for explanations), (3) Rates of evolution (calculated as the number of evolutionary changes (ECs) divided by the time over which these changes took place). Numbers before the slash $(/)$ are calculated rates for ACCTRAN and numbers following the slash are for DELTRAN. (4) The calculation of the rate between nodes $\mathrm{K}$ (Elephantinae, ca $6 \mathrm{Ma}$ ) and $\mathrm{L}$ (Elephantini, ca $4.5 \mathrm{Ma}$ ) is subsumed by the next two entries.

\begin{tabular}{|c|c|c|c|}
\hline Time span between & $\begin{array}{l}\text { Duration (time in } \\
\text { Ma, approximate) }\end{array}$ & $\begin{array}{l}\text { ECs along } \\
\text { this node (2) }\end{array}$ & $\begin{array}{l}\text { Calculated } \\
\text { rate (3) }\end{array}$ \\
\hline $\begin{array}{l}\text { Nodes } A \text { and } B-\text { ie between } \\
\text { Elephantiformes and Elephantimorpha }\end{array}$ & from 35 to 28 , span of 7 & $15 / 15$ & $2.14 / 2.14$ \\
\hline $\begin{array}{l}\text { Nodes } \mathrm{B} \text { and } \mathrm{C}-\text { ie between } \\
\text { Elephantimorpha and Elephantida }\end{array}$ & from 28 to 24, span of 4 & $13 / 13$ & $3.25 / 3.25$ \\
\hline $\begin{array}{l}\text { Nodes } \mathrm{C} \text { and } \mathrm{G}-\text { ie between } \\
\text { Elephantida and Elephantoidea }\end{array}$ & from 24 to 19, span of 5 & $40 / 35$ & $8.0 / 7.0$ \\
\hline $\begin{array}{l}\text { Nodes } \mathrm{G} \text { and } \mathrm{H}-\text { ie between } \\
\text { Elephantoidea and Elephantidae }\end{array}$ & from 19 to 7, span of 12 & $3 / 5$ & $0.25 / 0.42$ \\
\hline $\begin{array}{l}\text { Nodes } \mathrm{H} \text { and } \mathrm{K}-\text { ie between } \\
\text { Elephantidae and Elephantinae }\end{array}$ & from 7 to 6 , span of 1 & $15 / 16$ & $15 / 16$ \\
\hline $\begin{array}{l}\text { Nodes } \mathrm{K} \text { and Loxodonta - ie from the common } \\
\text { ancestor of Elephantinae to Loxodonta }\end{array}$ & from 6 to 0, span of 6 & $3 / 1$ & $0.50 / 0.17$ \\
\hline $\begin{array}{l}\text { Nodes } \mathrm{K} \text { and Elephas - ie from the common } \\
\text { ancestor of Elephantinae to Elephas (4) }\end{array}$ & from 6 to 0 , span of 6 & $5 / 7$ & $0.83 / 1.17$ \\
\hline $\begin{array}{l}\text { Nodes } \mathrm{K} \text { and Mammuthus - ie from the common } \\
\text { ancestor of Elephantinae to Mammuthus (4) }\end{array}$ & from 6 to 0 , span of 6 & $7 / 9$ & $1.17 / 1.50$ \\
\hline
\end{tabular}


weighting in parsinony analysis. Additionally, in our data, only one transversion occurred and it falls on the branch leading to the outgroup, Mammut. Therefore, a weighted parsimony analysis would not change the maximum parsimony tree topology and so it was not used.

\section{Calculating evolutionary rates}

Rates of evolution (calculated as the number of evolutionary changes (ECs) divided by the time over which these changes took place) provide a measure for understanding the evolution of lineages over a given geological time span. The time of divergence of each of the major proboscidean clades along the "spine". or major axis of the cladogram in Fig. 1A from Phiomia to Elephantini, was extrapolated from the illustrations and discussion of Maglio (1973), Coppens et al. (1978), Tassy and Shoshani (1996). The approximate dates of divergence in million years ago (Ma) are given under

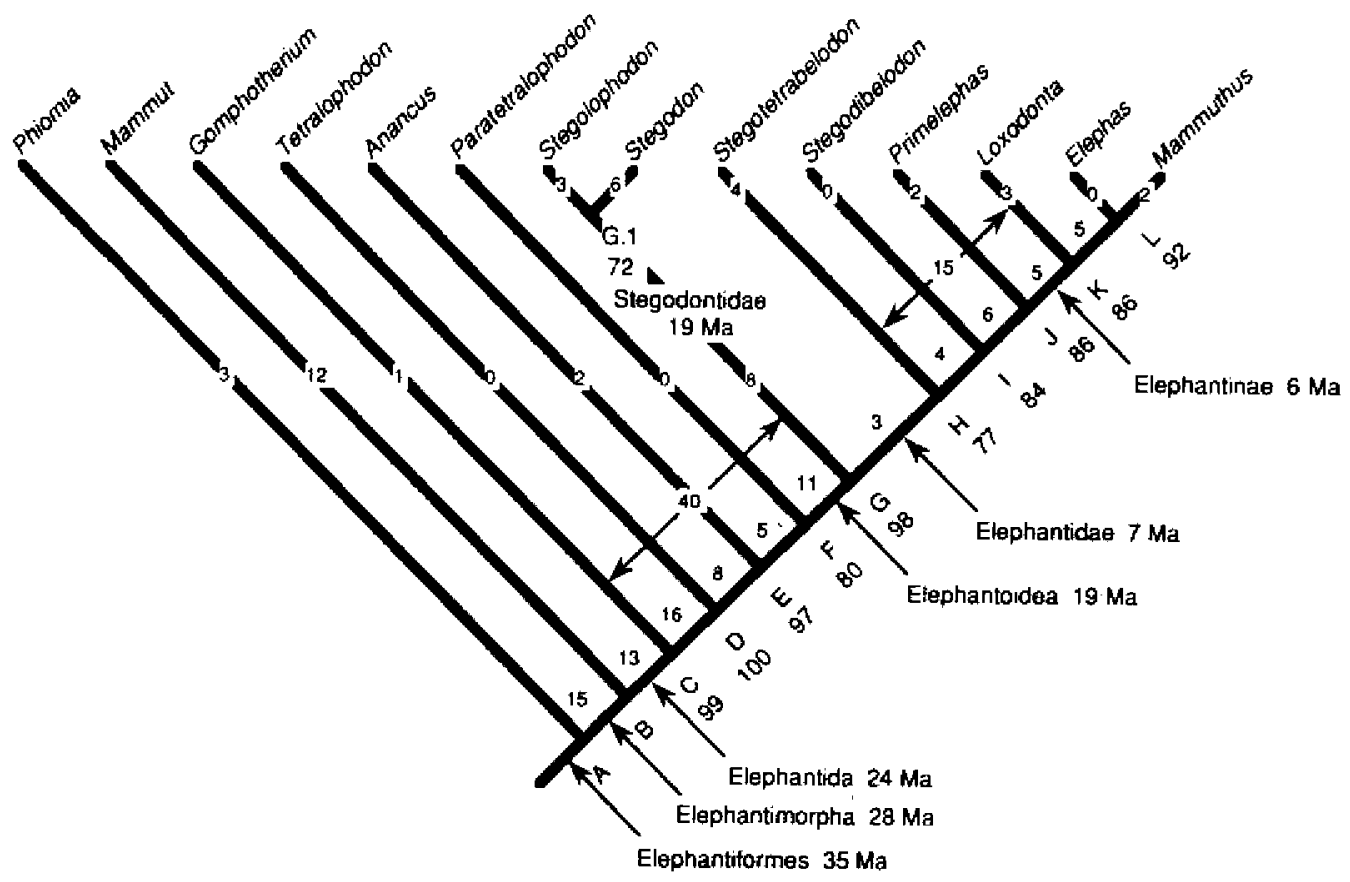

Fig. 1A. A maximum parsimony cladogram obtained with PAUP using 95 unordered characters on 14 taxa; tree length $(\mathrm{TL})=137$, Consistency Index $(\mathrm{CI})=0.78$, Retention Index $(\mathrm{RI})=0.84$. This cladogram was used to test phylogenetic hypotheses explained in Table 2, and testing the importance of outgroups among proboscidean taxa (Table 3). Letters along the main axis of this cladogram represent nodes/clades that are referred in Tables 1 and 4 . Numbers inside the cladogram (to the left of the main axis) and along the terminal taxa, represent evolutionary changes ( $\mathrm{ECs}$ ) for these clades or branches as obtained from the ACCTRAN option in PAUP**: Numbers outside the cladogram (to the right of the main axis) are bootstraps values based on 1,000 replications. **Numbers of ECs for these clades as obtained from DELTRAN option in PAUP are: node $\mathrm{B}-15$, node $\mathrm{C}-13$, node $D-13$, node $\mathrm{E}-8$, node $F-3$, node $\mathrm{G}-11$, node $G .1-3$, node $H-5$, node $I-3$, node $J-5$, node $K-8$, node $L-7$ (numbers in italics represent differences between ACCTRAN and DELTRAN). Differences in ECs for the terminal taxa, from left (Phiomia) to right (Mammuthus) are: Tetralophodon 2 vs 0, Paratetra. lophodon 1 vs 0 , Stegolophodon 4 vs 3, Stegodon 7 vs. 6, Stegodibelodon 1 vs 0 . Primelephas 3 vs 2 , and Loxodonta 1 vs 3 . Regardless of the differences for specific nodes or terminal taxa between ACCTRAN and DELTRAN, the total length of the tree remains the same-137 steps. The subfamily Elephantinae includes Primelephas as shown in Table 1. 
Results and discussion in parentheses after each of the subheadings below; cf Table 4 and Fig. 1A for names and geological times of approximate divergence (splitting) of taxa. Relative rates of cytochrome $b$ gene evolution among the terminal taxa, Loxodonta, Mammuthus, and Elephas, were determined using a relative rates test (Sarich and Wilson 1967 , Wu and $\mathrm{Li} 1985$ ). Sequence distances from these three taxa to Mammut americanum were determined using a Kimura two parameter estimate, using PHYLIP (Felsenstein 1993).

\section{Results and discussion}

\section{Morphological analysis}

Using the combined set of 95 characters shown in Appendix 1, the topology of the cladogram for the 15 taxa studied is depicted in Fig. 1A. For the purpose of direct comparison with the taxa employed in the molecular analysis (Fig. 2), we also present Fig. 1B which is a condensed version of Fig. 1A; it includes one ingroup (Elephantidae) and one outgroup (Mammut). Note that only one tree was obtained with PAUP analysis (no equally parsimonious trees).

Branch swapping was conducted on the cladogram (Fig. 1A); results are shown in Table 2. It is noted that the changes in the number of steps from the most parsimonious to other alternatives within Stegodontidae or within Elephantidae tested are small, ranging from one to five steps. Results confirm that Mammuthus and Elephas are more closely related to each other than either is to Loxodonta. Five additional steps are required when Mammuthus and Loxodonta or Elephas and Loxodonta are joined in a common branch (Table 2). It is also noted that, although members of the family Stegodontidae (Stegolophodon and Stegodon) are

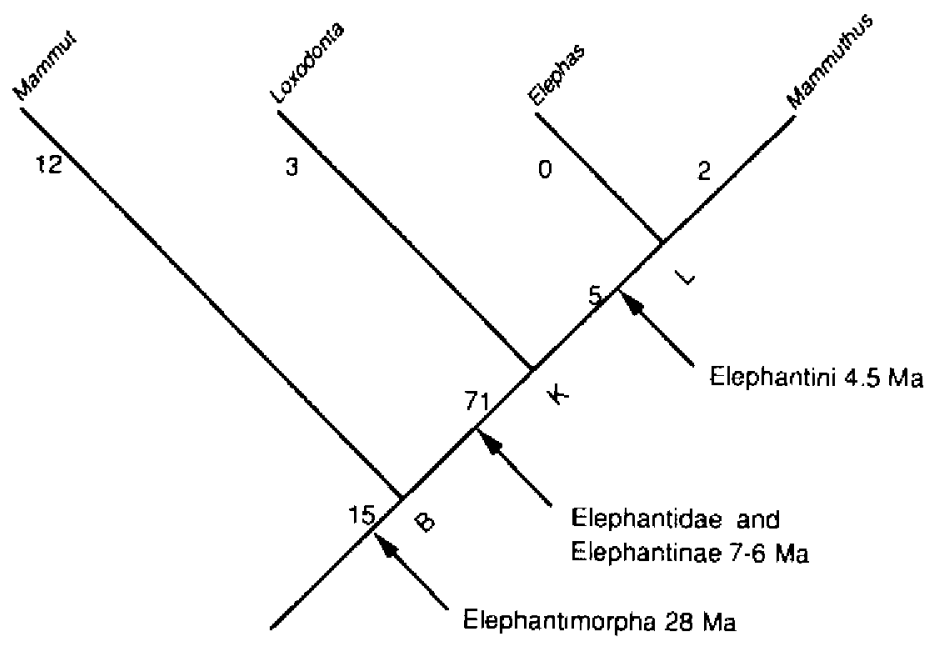

Fig. 1B. This is a condensed version of Fig. 1A which includes one ingroup (Elephantidae) and one outgroup (Mammut). Note that only one tree was obtained with PAUP analysis (no equally parsimonious trees; $\mathrm{TL}=60, \mathrm{CI}=1.0, \mathrm{RI}=1.0$ ); cf this tree to Fig. 2, obtained from molecular analysis. 


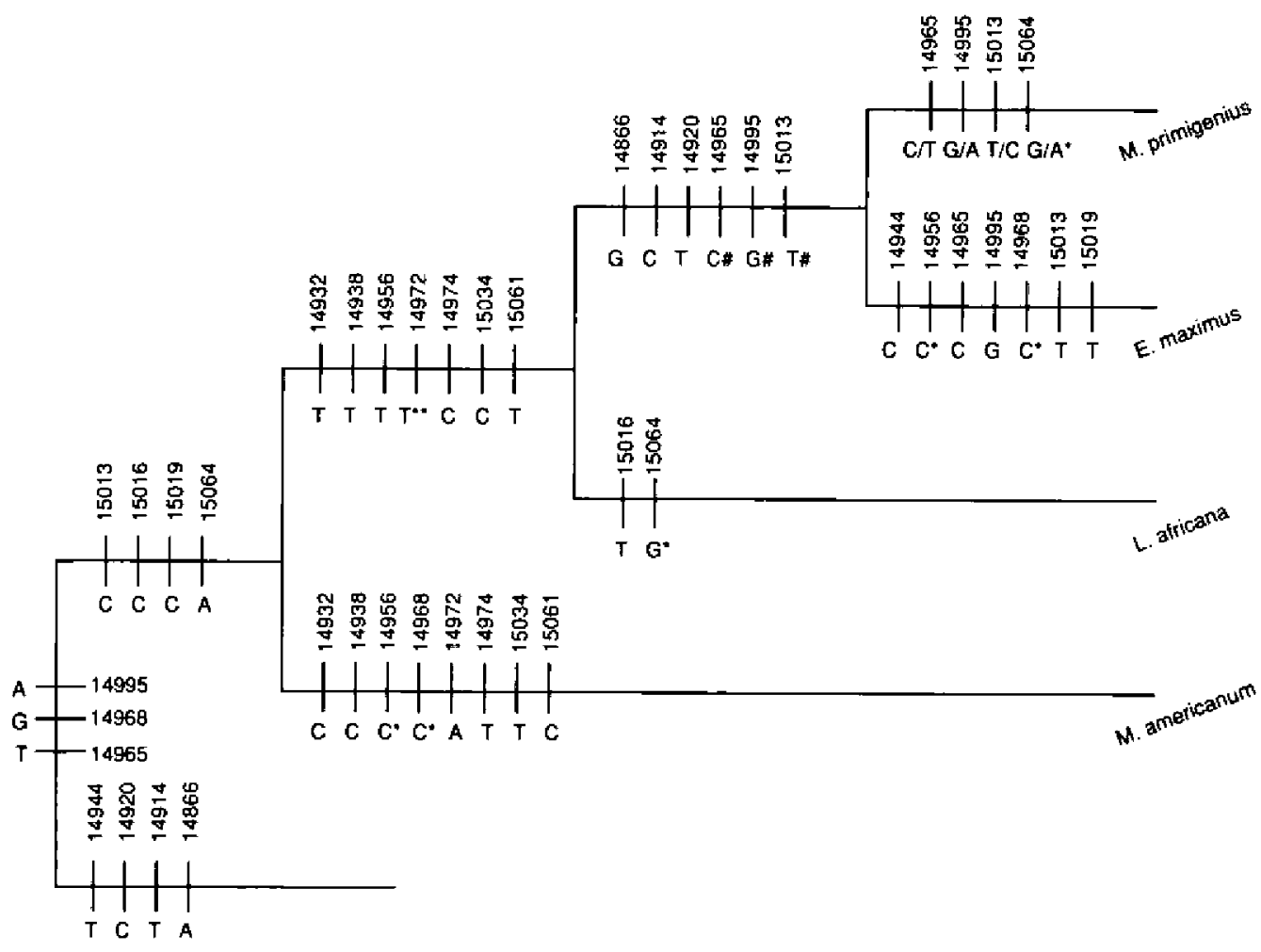

Fig. 2. A cladogram based on Neighbor joining and Maximum Parsimony tree of 228 base pairs mitochondrial gene cytochrome $b$ fragment of four proboscidean taxa (two extant and two extinct, after tree in Yang et al. (1996). Tree length (TL) $=23$, Consistency Index (CI) $=0.87$, Retention Index $(\mathrm{RI})=0.70$ ). Vertical bars indicate inferred bese composition at varjable sites within the sequence along branches. Nucleotide bases (character states) at sites that differ between the Elephantidae and Mammut cannot be unarbitrarily distinguished between ancestral and derived. Therefore, to display all character states for all variable sites, we list the nucleotides at these positions on both branches leading to Mammut and to Elephantidae. Our listing of these nucleotides does not imply two independent substitution events at each sequence position from an original ancestral state. Numbers are sequence position in reference to the human sequence (Anderson et al. 1981). Asterisks $\left(^{*}\right)$ indicate inferred homoplasies. Pound signs (\#) indicate inferred polymorphism along the branch of the most recent common ancestor. Characters listed on the root branch are inferred shared ancestral characters as opposed to the unique derived characters along terminal branches. Note that throughout this tree, all but one substitution are synonymous (there is no change in the product). The unique exception was observed in codon 75 (nucleic acid position 14972 of human numbering following Anderson et al. 1981 , indicated by ${ }^{* *}$ ) where Mammut sequence differed in a first position, non synonymous substitution. Also note that Mammuthus primigenius was paraphyletic in the original analysis; data on this branch represent two specimens.

monophyletic, breaking this clade costs only two additional steps - weak evidence, considering their long accepted history (since Osborn 1918) as a monophyly. Certainly, additional characters must be examined before a definite conclusion can be reached. 
A series of tests was conducted with the present morphological character matrix to evaluate the influence of outgroups on the cohesiveness of the ingroups. In these experiments, we deleted certain outgroup taxa from the matrix and ran PAUP to test whether the family Stegodontidae remained monophyletic as it was suggested by Saegusa (1996), Shoshani (1996), and Tassy (1996), or, if Stegolophodon and Stegodon would separate as suggested by Kalb et al. (1996). In ten of 12 tests, the Stegodontidae is monophyletic, whereas in two of 12 tests, Stegodon groups with Elephantidae, making Stegodontidae paraphyletic (Table 3). Outgroups that are phylogenetically closer to the ingroups are more reliable (more accurate) candidates for testing relationships within the ingroups, because the shorter branches (between the ingroup and the closer outgroup) have accumulated fewer mutations than shorter branches between the ingroup and the distantly related outgroup (Adachi and Hasegawa 1995, Yang et al. 1996). Less mutation results in fewer possibilities for parallelism and convergence, better polarization of characters, and overall better, and more accurate resolution of relationships among terminal taxa. Our results are corroborated by the vast majorities of similar studies (cf to references given above). This was also demonstrated by molecular data of Yang et al. (1996; further discussion below). We also noted that employing more than one outgroup (in our case, two or more) appears to be a more founded character polarity, and possibly a better resolution for taxa within the ingroups.

\section{Mammoths of Europe and Asia}

According to Lister (1996) and Lister and Bahn (1994), three lineages or successive stages of mammoths were present in Eurasia: the "ancestral mammoth", Mammuthus meridionalis (lived from about 3.0 to $0.7 \mathrm{Ma}$ ), the "steppe mammoth", $M$. trogontherii (lived from about 0.7 to $0.5 \mathrm{Ma}$ ), and "woolly mammoth", $M$. primigenius (lived from about 0.4 to $0.01 \mathrm{Ma}$ ). The evolutionary histories of these mammoths are complex and often intertwined (overlapping geological records and variations in characters). Nevertheless, these overall trends have been observed (Osborn 1942, Maglio 1973, Lister 1996): shift from long and low to short and high skull, including the brevirostry of the mandibular symphysis (antero-posterior compression); shift in the angle of tusk alveoli from projecting forward to projecting almost vertically downward; increase in angle of molar eruption; increase in lamellar frequency; increase in hypsodonty index; decrease in enamel thickness; and decrease in shoulder height. As can be noted, many of the characters are interlinked and may be considered as one, or suites of characters, eg antero-posterior cômpression of skull. By most accounts (summarized by Lister 1996), the morphology of $M$. trogontherii appears to be more derived than that of $M$. meridionalis. Thus, $M$. trogontherii more resembles $M$. primigenius than $M$. meridionalis. $M$. meridionalis appears to be the most plesiomorphic (among $M$. meridionalis, $M$. trogontherii, and $M$. primigenius) for these reasons: it has 
lamellae with median loops and presence of $\mathrm{P}^{4}$ as observed in one cranium (from Khapry, Russia). Median loops are vestiges of central conules found in gomphothere (more primitive proboscidean than $M$. meridionalis). Similarly, the presence of a permanent upper premolar is more often found in earlier, less advanced proboscideans, and thus is considered a primitive character, although it has been suggested that presence of $\mathrm{P}^{4}$ in certain crania of advanced proboscideans may be an atavistic character (Dubrovo 1989). Lister (personal communication) noted that the significance of the $\mathrm{P}^{4}$ in the Khapry $M$. meridionalis is uncertain because it has been observed in only one individual, so it might be considered an individual atavistic character.

\section{Mammoths of North and Central America}

A discussion of taxonomy and systematics of the North American mammoth was provided by Agenbroad (1994). According to Agenbroad (1984 - p. 91, 1994 p. 160), five mammoth species were present in North and Central America: the "Meridional mammoth", Mammuthus meridionalis (lived during the early Pleistocene, ca $1.8 \mathrm{Ma}-700000$ years BP), the "Imperial mammoth", $M$. imperator (lived during the middle Pleistocene, ca 700000-130000 years BP) the "Columbian mammoth", $M$. columbi, and the "Dwarf mammoth", $M$. exilis (lived during the early part of the late Pleistocene, ca $130000-10000$ years BP), and the "Woolly mammoth", $M$. primigenius (lived during the later part of the late Pleistocene, ca 40000 - 10000 years BP). Webb and Dudley (1995) reduced the number of mammoth species in North and Central America to three: $M$. hayi, $M$. columbi, and $M$. primigenius. In this scheme, $M$. hayi is considered the oldest mammoth in the New World (North and Central America; no mammoths are recorded from South America), instead of $M$. meridionalis, a hypothesis first proposed by Madden (1981). In addition, Webb and Dudley's (1995) formula could mean that $M$. columbi is composed of three subspecies, ie $M$. columbi columbi, $M$. c. jeffersonii, and $M$. c. exilis. Examination of characters of New World mammoths reveals that, as with the Eurasian mammoths, their evolutionary histories are complex. Nevertheless, the most important trend has been observed - the most primitive ones had fewer numbers of plates per given tooth and lower lamellar frequencies.

\section{Mammoth ancestry and inter-relationships}

Based on the available literature (eg Maglio 1973, Coppens et al. 1978, Agenbroad 1984, 1994, Lister and Bahn 1994, Webb and Dudley 1995, Lambert 1995, Lister 1996), the ancestry of mammoths may be simplified as follows (an arrow indicates possible direction of evolution). In Eurasia: $M$. meridionalis $\rightarrow M$. trogontherii $\rightarrow M$. primigenius. In North and Central America: $M$. hayi $\rightarrow M$. columbi. M. primigenius is an inmigrant to the New World. A possible progenitor 


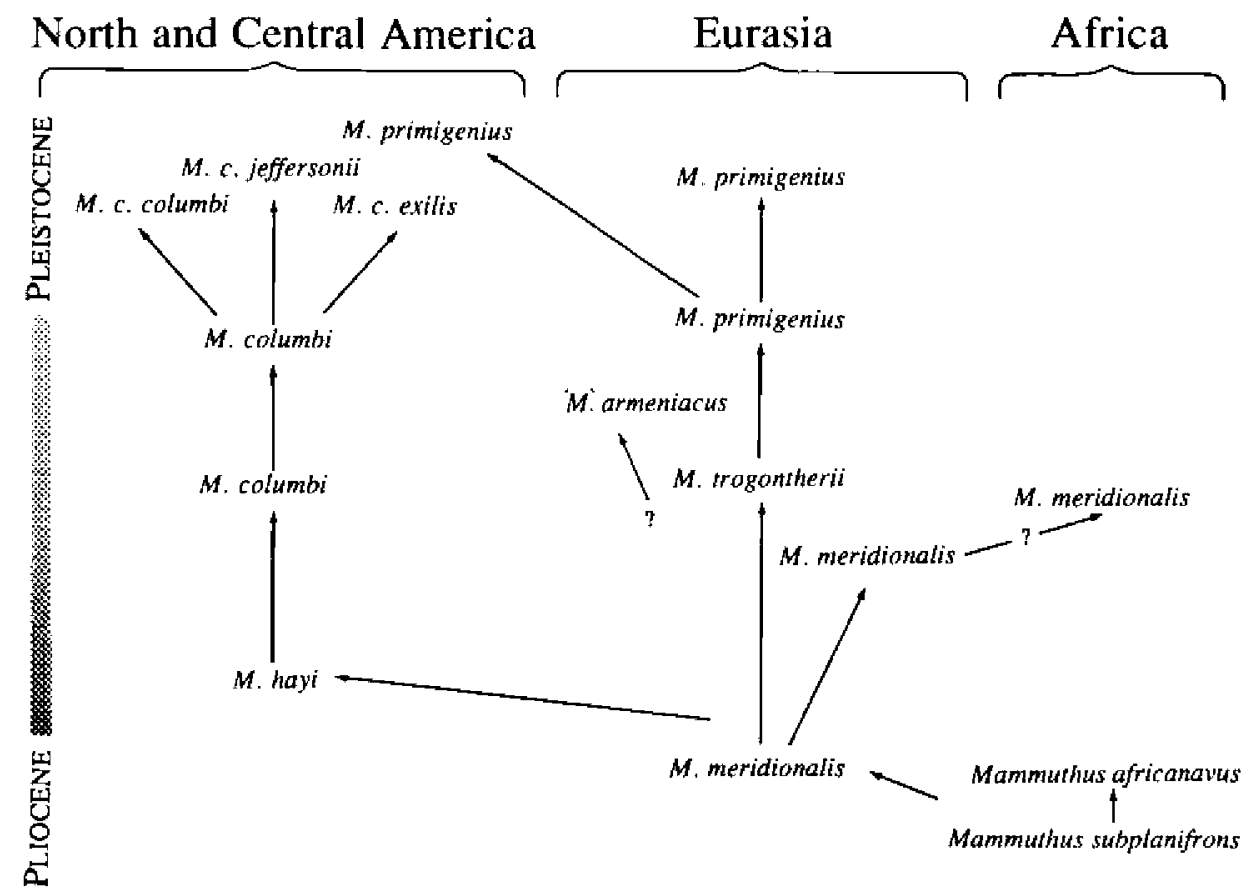

Fig. 3. A simplified possible mammoth ancestry and radiation in Africa, Eurasia and North and Central America. Sources for this chart include Maglio (1973, pp. 77, 79, 116-117), Agenbroad (1984, p. 91), Graham (1986, p. 169), Lister and Bahn (1994, pp. 11-35), Webb and Dudley (1995, pp. 654-657), Lister (1996, p. 203), Shoshani and Tassy 1996, pp. 361-362), Todd and Roth (1996, p. 198), and Webb (1996, p. 71A). The exact phylogenetic position of Mammuthus armeniacus is not known; A. M. Lister (pers. comm. 1997) suggested to place it in "Elephantidae incertae sedis". Mammuthus imperator (Leidy 1858) of North America is considered a junior synonym of $M$. columbi (Falconer, 1857) fide S. D. Webb (pers. comm. 1997). Artwork by Jann S. Grimes.

of $M$. hayi is $M$. meridionalis which may have arisen from $M$. africanavus or $M$. subplanifrons (cf Fig. 3).

\section{Molecular analysis}

A total of 228 base pairs of cytochrome $b$ gene sequences from four proboscidean taxa was used in phylogenetic analysis, and they were aligned with the published Loxodonta sequence of Irwin et al. (1991). Phylogenetic analysis was performed using domestic pig (Sus scrofa), black rhinoceros (Diceros bicornis), and human (Homo sapiens) sequences as outgroups, or, the fossil American mastodon (Mammut americanum) as an alternative outgroup. When modern non-proboscidean taxa (Sus, Diceros, Homo) were used as outgroups, all proboscideans were clustered together forming a monophyletic clade with Mammut as the first branching outgroup taxon. This monophyly is supported by $100 \%$ bootstrap resampling 
analysis. Nonetheless, the relationship among mammoths (Mammuthus) and the two modern elephants (Elephas and Loxodonta) could not be resolved above the $50 \%$ consensus level. On the other hand, when Mammut was added as the outgroup, both parsimony and neighbor-joining trees suggested that Elephas and Mammuthus formed a natural clade with Loxodonta as the sister-group. The topology is supported by relatively high bootstrap numbers (74\%), especially in comparison to a bootstrap support of $80 \%$ for monophyly of Loxodonta. This analysis demonstrates the effectiveness of using an appropriate outgroup for resolving phylogenies of highly derived elephantine lineages.

Long branches between the outgroups and ingroups could and do affect the relationships among the ingroup taxa. This phenomenon is probably more prevalent in molecular than morphological characters, because there is a bias in the ratio of transition to transversion substitutions (Transition substitutions are defined as a replacement of a purine (either adenine or guanine) with the other purine, or a replacement of a pyrimidine (cytosine or thymine) with the other pyrimidine. A transversion is defined as the substitution of a purine in place of a pyrimidine, or a pyrimidine in place of a purine). There are twice as many possible transversions as there are transitions. Yet, most studies indicate a clear predominance of transitions over transversions. The bias toward transitions is the result of a chemical process of most nucleotide base substitutions. When such a bias occurs on long branches, parallel and convergence mutations accumulate with time, and these mutations cause these long branches to be pulled together in a false clade. The best way to reduce or prevent such a bias is to choose an outgroup as closely related to the ingroup as possible.

Our molecular data also indicate that there is heterogeneity in evolutionary rates between Elephas-Mammuthus and Loxodonta clades relative to the common outgroup Mammut sequence. The Elephas-Mammuthus clade seems to have evolved at a more rapid rate relative to Loxodonta, in agreement with previous morphological data (Shoshani et al. 1985b). Caution should be taken with the interpretation of these results because our sequences are relatively short (228 base pairs).

\section{Evolutionary rates}

Table 4 provides approximate divergence times for taxa shown in Fig. 1A, followed by the evolutionary changes that occurred during this period and the calculated evolutionary rates (additional explanations are given under Material and methods). Letters for nodes/clades, number of evolutionary changes (EC) along a branch, and divergence times are included in Fig. 1A.

In summary, evolutionary rates of morphological characters display a relatively slow rate close to the ancestry of Proboscidea, followed by an acceleration along the branch from Elephantida to Elephantoidea (during the early and middle Miocene, from ca 24 to $19 \mathrm{Ma}$ ). This accelerated event was followed by a decelerated rate (during the late Miocene), followed by a burst of acceleration rate towards the suggested emergence and diversification of Elephantidae (from about the late 


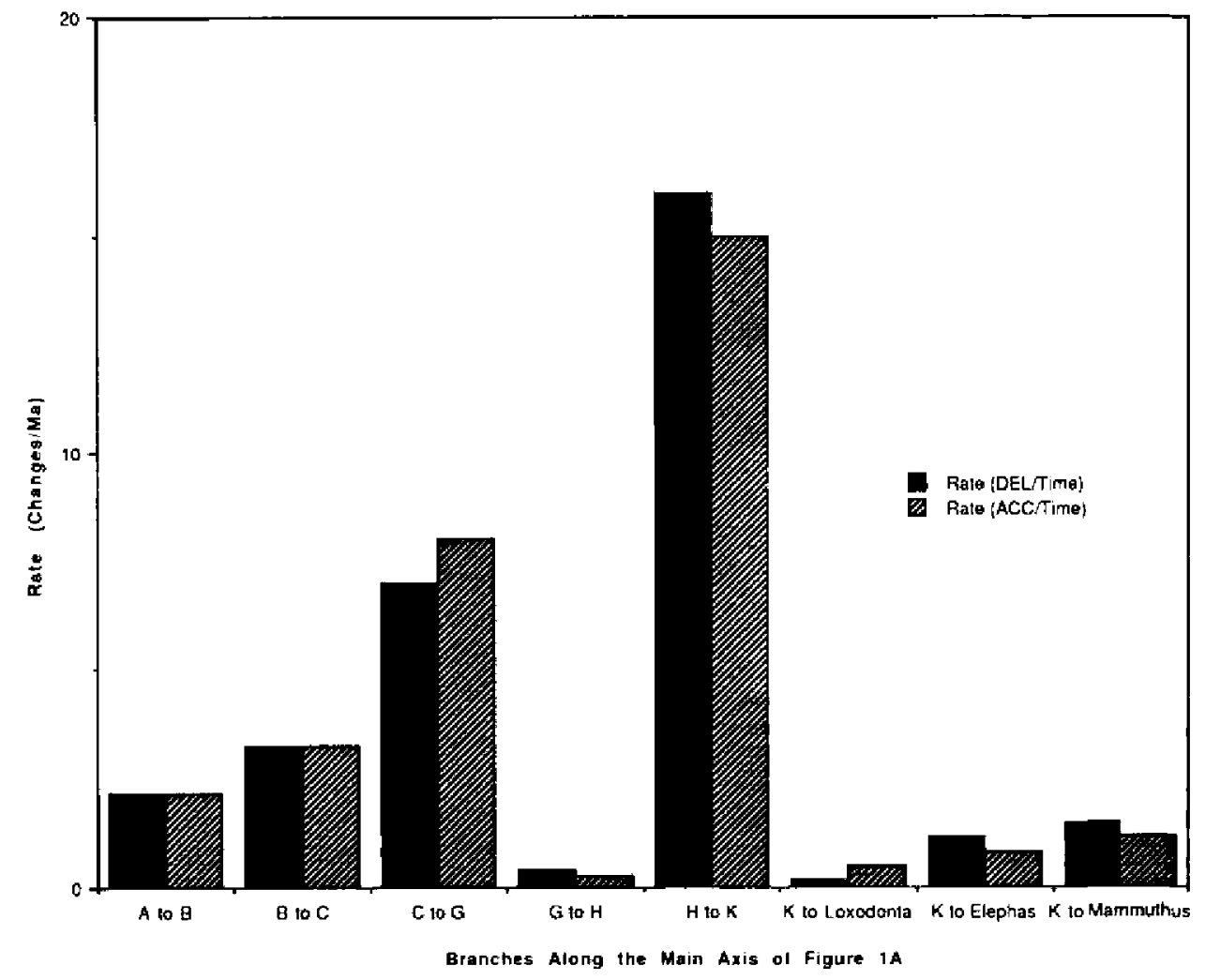

Fig. 4. Histograms depicting generalized patterns of evolutionary rates of morphological characters for the nodes/clades shown in Fig. 1A - main figure. Note the similarity between rates among elephantine taxa (Loxodonta, Elephas, and Mammuthus) shown here, and those of Maglis (1973, pp. 105-106)

Miocene to late Pliocene), and varying rates among Loxodontini and Elephantini taxa (Fig. 4). The observation of very fast acceleration at about the emergence of Elephantidae may be correlated with the fact that "... the Miocene saw major changes in global climate". The early Miocene "was warmer and had less seasonal variation than at any time ...", and by late Miocene, "a new low in averege global temperatures" was prevalent (Tattersall et al. 1988, pp. 350, 351). A burst of acceleration of morphological characters within Proboscidea may also be correlated with the newly available ecological niches that were utilized by certain dəveloping lineages.

Since the end of the Pliocene, at the time when Loxodontini and Elephantini diverged, through the end of the Pleistocene or Holocene, each lineace took a different adaptive path. Within these approximately six million years, evoutionary 
rate values for Loxodonta, Elephas, and Mammuthus were calculated to be 0.50 , 0.83 , and 1.17 , respectively (Table 4,4 th column, numbers on left of " $p$ "). These findings corroborate those of Maglio (1973) and of Shoshani et al. (1985b), indicating that Mammuthus was the fastest evolving genus, having evolved at about twice the rate of Loxodonta. Data from our molecular investigation indicate a $25-36 \%$ increase in rates of substitution in Elephas and Mammuthus compared to Loxodonta (Yang et al. 1996). It should be noted, however, that these differences do not reach statistical significance, presumably due to the small sequence length studied.

\section{Morphological vs molecular results: a comparison}

Focusing on the Elephantinae taxa (Loxodonta, Elephas, and Mammuthus) which were tested with both approaches, and only on the results when Mammut americanum was employed as an outgroup, we note the following.

In the morphological portion of this study we used 95 characters, whereas the molecular characters number 228. The maximum number of character states in the morphological data was $\operatorname{six}(0,1,2,3,4,5)$, whereas there are four possible character states ( $\mathrm{A}$ - adenine, $\mathrm{G}$ - guanine, $\mathrm{C}$ - cytosine, $\mathrm{T}$ - thymine) for the molecular characters. The number of characters is not significant as long as they are good and chosen objectively. The latter statement holds true for molecular more than for morphological data because of the possible subjectivity involved in choosing morphological characters. The number of character states is perhaps more significant than the number of characters because (when running PAUP with the unordered option), the greater the number of character states the more ambiguous the polarities of these character states will be (see also discussion in Shoshani et al. 1996); based on our experience, with such a small difference of six vs four the ambiguity of the polarities is not much different.

Cladistic analyses of morphological and molecular data support the traditional hypothesis that Mammuthus and Elephas are more closely related to each other than either is to Loxodonta. Mammut americanum proved to be an excellent choice as an outgroup for both, morphological and molecular studies, because of the recency of common ancestor within Proboscidea and because of the superb preservation of the bones that provided DNA for comparison with another extinct taxon (Mammuthus) and the two extant genera (Loxodonta and Elephas). Results with molecular data demonstrate the importance of using a closely related taxon as an outgroup for resolving phylogenies of highly derived species. The choice of a distantly related outgroup (outside of Proboscidea) would result in inferring evolutionary events over a long period of time (twice the time since the existence of the last common ancestor of the outgroup and ingroup). During this period, we assume that neutral nucleotide substitutions will accrue along both independent lineages (outgroup and ingroup). Because the gene sequence of interest must be evolving rapidly enough to distinguish hierarchical relationships among the 
Elephantinae, the gene sequences within the long independent lineages will accumulate a considerable number of substitutions. The result will be that distantly related gene sequences will be equally distinct from any terminal taxa within the ingroups, and will not, therefore, be useful in determining the hierarchical relationships of the inner nodes. This, in turn, results in incorrect rooting of the trees, especially when the branch lengths of the ingroups are heterogeneous. Evolutionary rates for the morphological characters indicate that among the Elephantinae, Loxodonta is the slowest evolving genus, followed by Elephas and Mammuthus. An indication for such rates was also obtained from the molecular data.

\section{Conclusions}

Results presented here are based on 95 morphological (osteological and dental) characters and 228 molecular characters (mtDNA base pairs). In the morphological part we studied 14 taxa (2 proboscidean outgroups, 4 gomphotheres, 2 stegodontids, and 6 elephantids), and in the molecular part we analyzed 7 taxa ( 3 non-proboscidean outgroups, 1 proboscidean outgroup, and 3 elephantids). Two of the proboscidean taxa studied by molecular methods are extinct genera, and were radiometrically dated between 46000 and 10220 years ago. Our results are summarized as follows:

(1) It is imperative that morphological characters are clearly defined and illustrated. Taxonomists must make special effort to describe morphological characters as clearly as possible; illustrations/photographs perhaps with arrows indicating exactly the nature of a character are very useful. In some cases, one misunderstanding or misinterpretation in the meaning of one writer by another can produce drastically different results, especially when the coding of a pivotal character produces different polarities by different interpreters. This type of subjectivity in describing characters is non-existent in molecular studies - the sequences (characters) are, in turn, analyzed by a computer (see discussion in Shoshani 1996, and Shoshani et al. 1996). One solution is collaborative studies, another is concentration on a few characters, but to study them thoroughly (this statement includes the works of Shoshani!).

(2) Cladistic analysis of morphological and molecular data corroborate the traditional hypothesis that Mammuthus and Elephas are more closely related to each other than either is to Loxodonta. Studying relationships within Elephantidae (using morphology or molecules) must not be conducted in isolation; the outgroup chosen - preferably within the Proboscidea - is an important decision, and two outgroups are better than one.

(3) It is extremely important to employ an outgroup which is closer (at least one which belongs in the same taxonomic order) to the ingroup - the closer the outgroup to the ingroup, the more accurate the results will be. In addition, more 
than one outgroup will probably help to define the transformation (morphoclines; ie, changes that occur from one character state to another with one character) of characters and their polarities.

(4) Stegotetrabelodon and Stegodibelodon, once thought to belong in one subfamily (Stegotetrabelodontinae; Maglio 1973, Coppens et al. 1978), do not remain grouped in one clade. Stegodibelodon is a sister-group to Elephantinae followed by Stegotetrabelodon, a relationship also corroborated by the studies of Kalb et al. (1996), and Shoshani (1996). It costs three additional steps to support Maglio's (1973) hypothesis (cf Table 2).

(5) Our findings also suggest that the family Stegodontidae (Stegolophodon and Stegodon) is a monophyletic taxon although with weaker support than for relationships within the Elephantinae. Kalb et al. (1996) hypothesized that Stegodontidae is not a monophyletic taxon.

(6) Recent detailed studies of Eurasian and North American mammoths indicate that their evolutionary histories are complex and often intertwined with overlapping geological records and variations in characters. Despite these complications, overall trends have been observed, and they can be summarized by observing changes in the skull - from low and long in primitive taxa to high and short in more advanced ones - and also by increase of lamellar frequencies through geological ages.

(7) Mammutidae (here represented by Mammut) is not a sister-group to Stegodontidae. Manmutidae is the plesiomorphic sister-group to the clade comprising all gomphotheres, stegodontids, and elephantids. The close association of Tetralophodon, Anancus, and Paratetralophodon with Stegodontidae and Elephantidae corroborates the hypothesis that Stegodontidae is more closely related to gomphotheres and elephantids than to mammutids.

(8) The gomphotheres, sensu lato, are definitely not a monophyletic assemblage, a conclusion also reached by Tassy (1996) and Shoshani (1996).

(9) Calculated evolutionary rates for the morphological and molecular characters indicate that among the three elephantine genera studied, Mammuthus had evolved at the fastest rate, followed by Elephas, and then, Loxodonta. For the given characters we studied, autapomorphies along the Mammut branch are greater in the morphological than in the molecular characters (12 vs 8 ; cf Fig. IB to Fig. 2).

(10) The suggested partial classification for the proboscidean taxa studied (Table 1) is based on the works of several authors (eg Shoshani 1986, 1996, Tassy and Darlu 1986, Kalb et al. 1996, Tassy 1996), and is not intended to present a "final" branching pattern among these taxa - it is only a tentative working hypothesis based on the available evidence.

Acknowledgements: Staffs of the museums listed above, who allowed us to study specimens in their care and/or collect samples for DNA analyses, are deeply appreciated. Individuals who helped us in various aspects of this study include: J. Alexander, S. K. Bell, D. Domning, M. Goodman, J. S. Grimes, J. E. Kalb, A. M. Lister, M. C. McKenna, E. C. Marsac, J. L. Pierce, H. Saegusa, P. Tassy, R. Tedford, 
and S. D. Webb. Tassy's ( 1990 and 1996) characters were invaluable and discussions of their polarities were pivotal. A. M. Lister's and S. D. Webb's help with simplifying and correcting the mammoth evolutionary chart (Fig. 3, drawn by J. S. Grimes) is much appreciated. Molecular studies of ancient proboscideans were supported, in part, by Alfred P. Sloan Foundation fellowship (93-4-6-ME) to H. Y.

\section{References}

Adachi J. and Hasegawa M. 1995. Phylogeny of whales: dependence of inference on species sampling. Molecular Biology and Evolution 12: 177-179.

Agenbroad L. D. 1984. New World mammoth distributions. [In: Quaternary extinctions: a prehistoric revolution. P. S. Martin and R. G. Klein, eds]. University of Arizona Press, Tucson: 90-108.

Agenbroad L. D. 1994. Taxonomy of North American Mammuthus and biometrics of the Hot Springs mammoths. [In: The Hot Springs Mammoth Site: a decade of field and laboratory research in paleontology, geology, and paleoecology. L. D. Agenbroad and J. I. Mead, eds]. The Mammoth Site of South Dakota, Hot Springs: 158-207.

Aguirre E. E. 1969. Evolutionary history of the elephant. Seience 164 (3886): 1366-1376.

Anderson S., Bankier A. T., Barrell B. G., de Brujin M. H. L., Coulson A. R., Drouin J., Eperon I. C., Nierlich D. P., Roe B. A., Sanger F., Schreier P. H., Smith A. J. H., Staden R. and Young I. G. 1981. Sequence and organization of the human mitochondrial genome. Nature (London) 290: $457-465$.

Barnard G. F., Pude R. M., Begum N. A. and Chen L. B. 1994. PCR product sequencing with (a-33P) and (a-32P) dATP. BjoTechniques 16: 572-573.

Blumenbach J. F. 1779 . Handbuch der Naturgeschichte (1st edn). J. H. Dieterich, Göttingen: 1-559.

Boom R., Sol C. J. A., Salimans M. M. M., Jansen C. L., Wertheim-van Dillen P. M. E. and van der Nordaa J. 1990. Rapid and simple method for purification of nucleic acids. Journal of Clinical Microbiology 28: 495-503.

Cano R. J. and Poinar H. N. 1993. Rapid isolation of DNA from fossil and museum specimens suitable for PCR. BioTechniques 15: 432-435.

Cooper A. 1994. DNA from museum specimens. [In: Ancient DNA. B. Herrmann and S. Hummel, eds]. Springer-Verlag, New York: 149-165.

Coppens Y., Maglio V., Madden C. T. and Beden M. 1978. Proboscidea. IIn: Evolution of African mammals. V. J. Maglio and H. B. S. Cooke, eds]. Harvard University Press, Cambridge, Massachusetts: $336-367$.

Cuvier F. 1825. Eléphant d'Afrique. IIn: Histoire naturelle des Mammiferes, avec des figures originales, coloriées, dessinées d'après des animaux vivants: publiée sous l'autorité de l'administration du Museum d'Histoire Naturelle. E. Geoffroy Saint-Hilaire and F. Cuvier, eds, for the years of 1824-1847, 7 volumes]. Belin, Paris: 1-2 +1 plt. Volume 3, A.

Doyle J. J. and Doyle J. L. 1987. A rapid DNA isolation procedure for small quantities of fresh leaf tissue. Phytochemical Bulletin 19: 11-15.

Dubrovo L. A. 1989. Systematic position of the Khapry elephants. Paleontologicheskii Zhurnal 1989/1: $78-87$.

Ezra H. C. and Cook S. F. 1959. Histology of mammoth bone. Science 129: 465-466.

Felsenstein J. 1993. PHYLIP (Phylogeny Inference Package), Version 3. Department of Genetics, University of Washington, Seattle, Washington: 1-5.

Golenberg E. M. 1994. DNA from plant compression fossils. [In: Ancient DNA. B. Herrmann and S. Hummel, eds]. Springer Verlag, New York: 237-256.

Graham R. W. 1986. Taxonomy of North American mammoths. [In: The Colby mammoth site taphonomy and archaeology of a Clovis kill in northern Wyoming. G. C. Frison and L. C. Todd, eds|. University of New Mexico Press, Albuquerque: $165-169$.

Groves C., Grubb P. and Bricknell S. 1993. Taxonomy of African elephants. Abstracts, Sixth International Theriological Congress, Sydney, Australia, 4-10 July 1993: 120. 
Hagrelberg E. and Clegg J. B. 1991. Isolation and characterization of DNA from archaeological bone. Proceedings of the Royal Society of London: B, 244: $45-50$.

Hagelberg E., Thomas M. G., Cook C. E., Sher A. V., Baryshnikov G. F. and Lister A. M. 1994. DNA from ancient mammoth bones. Nature 370: 333-334.

Hardy C., Casane D., Vigne J. D., Callou C., Dennebouy N., Mounolou J.-C. and Monnerot M. 1994. Ancient DNA from Bronze Age bones of European rabbit (Oryctolagus cuniculus). Experientia 50: $564-570$.

Höss M. and Pääbo S. 1993. DNA extraction from Pleistocene bones by a silica-based purification method. Nucleic Acids Research 21: 3913-3914.

Höss M., Pääbo S, and Vereschagin N. K. 1994. Mammoth DNA sequences. Nature 370; 333.

Irwin D. M., Kocher T. D. and Wilson A. C. 1991. Evolution of the cytochrome $b$ gene of mammals. Journal of Molecular Evolution 32: 128-144.

Jones C. 1984. Tubulidentates, proboscideans, and hyracoideans. In: Orders and families of Recent mammals of the world. S. Anderson and J. K. Jones, Jr, eds]. John Wiley \& Sons, New York: $523-535$.

Kalb J. E., Froehlich D. J. and Bell G. L. 1996. Phylogeny of African and Eurasian Elephantoidea of the late Neogene. [In: The Proboscidea: evolution and palaeoecology of elephants and their relatives. J. Shoshani and P. Tassy, eds]. Oxford University Press: 101-116.

Krause H. 1978. The mammoth - in ice and snow? Cold-adaptation of woolly mammoth: fact or fiction? Self-publisher, Stuttgart: $1-107+1$ page Epilog-

Kumar S., Tamur K. and Nei M. 1993. MEGA; molecular evolutionary genetics analysis 1.01. The Pennsylvania State University, University Park.

Lambert W. D. 1995. Mammuthus from the late Blancan Santa Fe 1B locality: the oldest record of Mammuthus in North America. Journal of Vertebrate Paleontology 15 (3, Supplement): 40A.

Lister A. M. 1996. History and taxonomy of Eurasian mammoths. [In: The Proboscidea: evolution and palaeoecology of elephants and their relatives. J. Shoshani and P. Tassy, eds!. Oxford University Press: 203-213.

Lister A. M. and Bahn P. 1994. Mammoths. MacMillan, New York: 1-168.

Lowenstein J. M. and Shoshani J. 1996. Proboscidean relationships based on immunological data. [In: The Proboscidea: evolution and palaeoecology of elephants and their relatives. J. Shoshani and P. Tassy, eds]. Oxford University Press: 49-54.

Lydekker R. 1907. The ears as a race-character in the African elephant. Proceedings of the Zoological Society of London 26: 380-403.

Lydekker R. 1916. Catalogue of the ungulate mammals in the British Museum (Natural Historyl 5; 1-207.

Madden C. T. 1981. Mammoths of North America, Unpublished Ph D thesis. University of Colorado, Boulder. University Microfilms, Ann Arbor: 1-271.

Maddison W. P. and Maddison D. R. 1992. MacClade: analysis of phylogeny and character evolution. Version 3.0. Computer program distributed by Sinauer Associates, Sunderland, Massachusetts.

Maglio V. J. 1973. Origin and evolution of the elephantidae. Transactions of The American Philosophical Society of Philadelphia. New Series 63(3): 1-149.

McKenna M. C., Bell S. K., Simpson G. G., Nichols R. H., Tedford R. H., Kooprnan K. F., Musser G. G., Neff N. A., Shoshani J. and McKenna D. M. 1997. Classification of mammals above the species level. Columbia University Press, New York: 1-631.

Osborn H. F. 1918. March. A long-jawed mastodon skeleton from South Dakota and phylogeny of the Proboscidea. (Abstract) Bulletin of the Geological Society of America 29: 133-137.

Osborn H. F. 1921. The evolution, phylogeny, and classification of the Proboscidea. American Museum Novitates 1: 1-15.

Osborn H. F. 1936. Proboscidea: a monograph on the discovery, evolution, migration and extinction of the mastodonts and elephants of the world. Vol. I: Moeritherioidea, Deinotherioidea, Mastodontoidea. The American Museum Press, New York: 1: xl + 1-802 (page 802 includes errata). 
Osborn H. F. 1942. Proboscidea: a monograph of the discovery, evolution, migration and extinction of the mastodonts and elephants of the world. Vol. II: Stegodontoidea, Elephantoidea. The American Museum Press, New York: xxvii $+805-1675$ (plus one errata page).

Ozawa T., Hayashi S. and Mikhelson V. M. 1997. Phylogenetic position of mammoth and Steller's sea cow within Tethytheria demonstrated by mitochondrial DNA sequences. Journal of Molecular Evolution 44: $406-413$.

Saegusa H. 1996. Stegodontidae: evolutionary relationships. [In: The Proboscidea: evolution and palaeoecology of elephants and their relatives. J. Shoshani and P. Tassy, eds]. Oxford University Press: $178-190$.

Sarich V. M. and Wilson A. C. 1967. Immunological time scale for hominid evolution. Science 158 : $1200-1203$.

Shoshani J. 1986. On the phylogenetic relationships among Paenungulata and within Elephantidae as demonstrated by molecular and osteological evidence. Unpublished $\mathrm{Ph} \mathrm{D}$ thesis, Wayne State University, Detroit (Michigan). Michigan University Microfilms, Ann Arbor: 1-649.

Shoshani J. 1993. How many species or subspecies of forest Loxodonta exist? Abstracts, Sixth International Theriological Congress, Sydney, Australia, 4-10 July 1993: 278-279.

Shoshani J. 1996. Para- or monophyly of the gomphotheres and their position within the Proboscidea. In: The Proboscidea: evolution and palaeoecology of elephants and their relatives. J. Shoshani and P. Tassy, eds]. Oxford University Press: 149-177.

Shoshani J. 1998. Understanding proboscidean evolution: a formidable task. Trends in Ecology and Evolution 13: 480-487.

Shoshani J. and Tassy P. (eds) 1996. The Proboscidea: evolution and paleoecology of elephants and their relatives. Oxford University Press: 1-472.

Shoshani J. et al. [76 co-authors] 1982. On the dissection of a female Asian elephant (Elephas maximus maximus Linnaeus, 17581 and data from other elephants. Elephant 2: 3-93.

Shoshani J., Fisher D. C., Zawiskie J. M., Thurlow S. J., Shoshani S. L., Benninghoff W. S. and Zoch F. H. 1989. The Shelton Mastodon Site: a multidisciplinary study of a late Pleistocene (Twocreekan) locality in southeastern Michigan. Contributions from the Museum of Paleontology, the University of Michigan 27: 393-436.

Shoshani J, Groves C. and Simons E. 1996. Primate phylogeny: morphological vs. molecular results. Molecular Phylogenetics and Evolution 5: 102-154.

Shoshani J., Lowenstein J. M., Walz D. A. and Goodman M. 1985a. Proboscidean origins of magtodon and woolly mammoth demonstrated immunologically. Paleobjology 11: 429-437.

Shoshani J., Walz D., Goodman M., Lowenstein J. M. and Prychodko W. 1985b. Protein and anatomical evidence of the phylogenetic position of Mammuthus primigenius within the Elephantinae. Acta Zoologica Fennica 170: 237-240.

Swofford D. L. 1993. PAUP: phylogenetic analysis using parsimony. Version 3.1.1. Computer program distributed by the Illinois Natural History Survey, Champaign, Illinois: 1-257.

Tassy P. 1988. The classification of Proboseidea: how many cladistic classifications? Cladistics 4: $43-57$.

Tassy P. 1990. Phylogenie et classification des Proboscidea (Mammalia): historique et actualité. Annales de Paléontologie (Vert.-Invert.) 76: 159-224.

Tassy P. 1996. Who is who among the Proboscidea? In: The Proboscidea: evolution and palaeoecology of elephants and their relatives. J. Shoshani and P. Tassy, eds!- Oxford University Press: 39-48.

Tassy P. and Darlu P. 1986. Analyse cladistique numérique et analyse de parcimonie: l'exemple des Elephantidae. Géobios 19: 587-600.

Tassy P. and Shoshani J. 1988. The Tethytheria: elephants and their relatives. IIn: The phylogeny and classification of the tetrapods. Volume 2: Mammals. M. Benton, ed]. The Systematics Association, Special Volume No. 35B. Clarendon Press, Oxford: 283-315.

Tassy P. and Shoshani J. 1996. Historical overview of classification and phylogeny of the Proboscidea. In: The Proboscidea: evolution and palaeoecology of elephants and their relatives. J. Shoshani and P. Tassy, eds]. Oxford University Press: $3-8$. 
Tattersall I., Delson E. and Van Cuuvering J. 1988. Encyclopedia of human evolution and prehistory. Garland Publishing, New York: 1-603.

Tobien H. 1976. Zur paläontologischen Geschichte der Mastodonten (Proboseidea, Mammalia). Mainzer Geowissenschaftliche Mitteilungen 5: 143-225.

Tobien H. 1988. Some major features in the evolution of mastodonts (Proboscidea, Mammalia). Geological Survey of India, Special Publication No 11: 109-116.

Todd N. E. and Roth V. L. 1996. Origin and radiation of the Elephantidae. [In: The Proboscidea: evolution and palaeoecology of elephants and their relatives. J. Shoshani and P. Tassy, eds]. Oxford University Press: 193-202.

Valente A. 1983. Hair structure of the woolly mammoth, Mammuthus primigenius and the modern elephants, Elephas maximus and Loxodonta africana. Journal of Zoology, London 11: 271-274.

Webb S. D. 1996. Evolution of mammoths in North and Central America. Journal of Vertebrate Paleontology 16 (3, Supplement): 71A.

Webb S. D. and Dudley J. P. 1995. Proboscidea from the Leisey Shell Pits, Hillsborough County, Florida. [In: Paleontology and geology of the Leisey Shell Pit, early Pleistocene of Florida. R. C. Hulbert, Jr, G. S. Morgan and S. D. Webb, eds]. Bulletin of the Florida Museum of Natural History, Biological Sciences 37, Part II(20): 645-660.

Wu C.-I. and Li W.-H. 1985. Evidence for higher rates of nucleotide substitution in rodents than in man. Proceedings of the National Academy of Science, USA 82: 1741-1745.

Yang H., Golenberg E. M. and Shoshani J. 1996. Phylogenetic resolution within the Elephantidae using fossil DNA sequence from American mastodon (Mammut americanum) as an outgroup. Proceedings of the National Academy of Sciences 93: 1190-1194.

Yang H., Golenberg E. M. and Shoshani J. 1997a. A blind testing design for authenticating ancient DNA sequences. Molecular Phylogenetics and Evolution 7: 261-265.

Yang H., Golenberg E. M. and Shoshani J. 1997b. Proboscidean DNA from museurn and fossil specimens: an assessment of ancient DNA extraction and amplification techniques. Biochemical Genetics 35: 165-179.

Received 23 March 1998, accepted 30 May 1998. 
Appendix 1. Proboscidean characters examined to test hypotheses discussed in this study. * Characters in this table are from three main sources: Shoshani (1996, pp. 162-166), Tassy and Darlu (1986, pp. 599-600), and Kalb et al. (1996, p. 104). Each set of characters is listed separately for easy reference. Sequential numbers are given first and these are followed (in parentheses) by the original number of the authors to make it easy to trace the sources. This system is also folowed in Appendix 2, where the numbers at the top are sequential, and the numbers beneath them are from the original papers.

* Characters from Shoshani (1996) are adapted from, or slightly modified after many sources, details and key to references are given in Shoshani (1996, p. 162). Whenever possible, characturs were observed on adult individuals, and at least three specimens were examined for each taxon (other details under Material and methods). Characters are arranged from anterior to posterior of body, beginning with incisors.

Note K18a: In characters K18 through K22, the word "plates" does not define which plater. This is confusing because the configuration of the posterior and anterior face of each lophid or lowe: plate is different at the anterior, middle, and posterior of a tooth. We have not attempted to correct ir modify Kalb et al.'s data for this question, but placed a "?" for Stegolophodon and Stegodon because they are most likely to be incorrectly coded and are the crux of the main disagreement between Kalb et $a l$. (1996) results compared to other authors (eg Tassy and Darlu 1986, Saegusa 1996, Shoshaji 1996). Note K 18b: "absent" under character state (1) may be interpreted as if is not "very conver" or not "shallow convex", in which case some taxa, eg, Stegolophodon and Stegodon might be coded vith "?"or " 0 ".

\begin{tabular}{ccc}
\hline Feature & Primitive (only state " 0 ") & Derived (all states excep1 " 0 ) \\
\hline 1 & 2 & 3 \\
\hline
\end{tabular}

1(7). UPPER TUSKS: viewed laterally

2(10). UPPER TUSKS: ename]

3(11). LOWER TUSKS: viewed laterally 4(12). LOWER TUSKS: viewed anteriorly 5(13). LOWER TUSKS: protruding portion, viewed dorsally 6(15). LOWER TUSKS:

7(16). LOWER TUSKS: medial edge $8(22), \mathrm{dp}_{\mathrm{p}}^{2}$ : parastyle 9(23). $\mathrm{dp}^{3}:$ posterior loph (oblique, ie metacone displaced posterior to hypocone) $10(24) . \mathrm{dp}^{3}$ : oblique contact between pre- and posttrite central conule 11(25). dp3: oblique contact between pre- and posttrite central conule
Part I - Characters after Shoshani (1996) $(0)=$ curve ventrally $\quad(1)=$ straight

(2)=curve dorsally

(3)=curve dorsally, much

(0)=surrounds tooth $\quad(1)=$ partly surrounds tooth

(2)=a longitudinal band of entmel

(3)=little or usually absent

(4)=enamel absent

(0)=curve dorsally (1)=straight

(2)=curve ventrally

(0)=wear at tip, anteriorly (1)=wear at tip, dorsally and rentrally (2)=wear at tip, ventrally only

$(0)=$ small (less than $\quad(1)=$ longer than approximatel $10 \mathrm{~cm}$

$10 \mathrm{~cm}$ long)

$(0)=$ cross section (c.s.) flat $(1)=$ c.s. pyriform

(2)=round or oval

$(0)=$ round

(1)=straight

$(0)=$ not reduced $\quad(1)=$ reduced

$(0)=$ not oblique $\quad(1)=$ oblique

\section{(0) $=$ absent \\ (1)=present}

$(0)=a b s e n t$

(1)=present 
Appendix I - continued

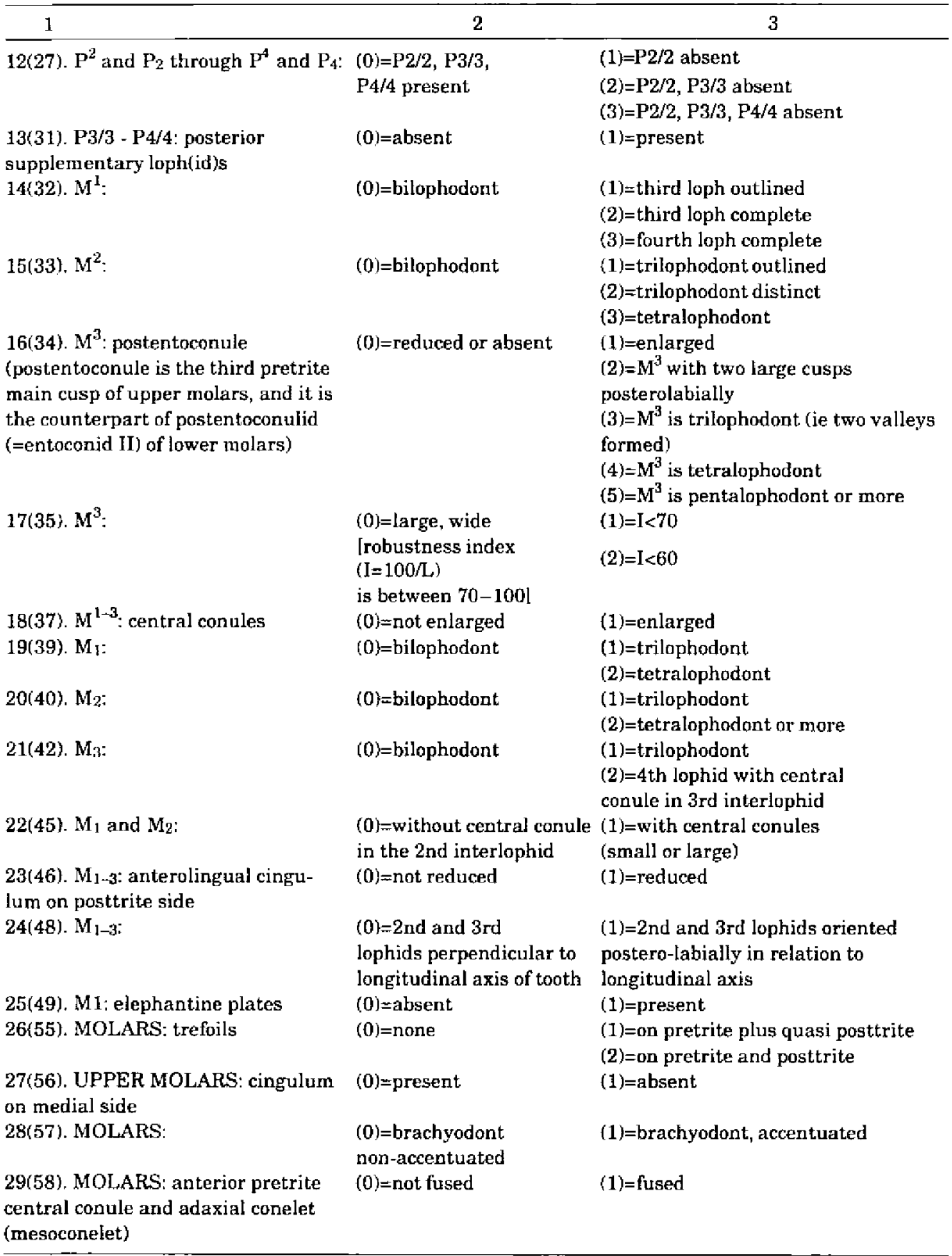


Appendix 1 - continued

\begin{tabular}{|c|c|c|}
\hline 1 & 2 & 3 \\
\hline $\begin{array}{l}\text { 30(59). MOLARS: abaxial and } \\
\text { adaxial cones (and their conelets) }\end{array}$ & $(0)=$ are of unequal size & (1)=are of about equal size \\
\hline 31(60). MOLARS' PATTERN & $(0)=$ with cusps or lophs & $\begin{array}{l}(1)=\text { with laminae } \\
(2)=\text { laminae with height/width }=1,1+ \\
\text { or more }\end{array}$ \\
\hline $\begin{array}{l}\text { 32(61). MOLARS: with thinner } \\
\text { and more numerous laminae }\end{array}$ & $(0)=a b \operatorname{sen} t$ & (1)=present \\
\hline $\begin{array}{l}\text { 33(62), PREMOLARS and MOLARS: } \\
\text { Note: "zygodont" refers to the outline } \\
\text { of ridges in anterior view; they are } \\
\text { 'yoke-shaped' and sharp when worn }\end{array}$ & $(0)=$ non-zygodont & (1)=zygodont \\
\hline $\begin{array}{l}\text { 34(63). PREMOLARS and MOLARS: } \\
\text { crowns of } \\
\text { 35(64). PREMOLARS and MOLARS: } \\
\text { hypsodonty index }\end{array}$ & $\begin{array}{l}(0)=\text { cement absent } \\
(0)=\text { brachyodonty }\end{array}$ & $\begin{array}{l}\text { (1)=little cement present } \\
\text { (2)=abundant cement present } \\
\text { (1)=hypsodonty }\end{array}$ \\
\hline $\begin{array}{l}\text { 36(65). PREMOLARS and MOLARS: } \\
\text { central conule in a form of a crest } \\
\text { and does not block the valley }\end{array}$ & $(0)=a b s e n t$ & (1) $=$ present \\
\hline $\begin{array}{l}\text { 37(66). PREMOLARS and MOLARS: } \\
\text { zygodont crest on posttrite }\end{array}$ & $(0)=$ absent & (1)=present \\
\hline $\begin{array}{l}\text { 38(67). CHEEK TEETH: horizontal } \\
\text { displacement and succession associated } \\
\text { with remodeling of adjacent bones }\end{array}$ & $(0)=$ absent & $(1)=$ present \\
\hline 39(73). CRANIUM: & $\begin{array}{l}(0)=\text { swelling absent } \\
\text { (saggital crest present) }\end{array}$ & $\begin{array}{l}\text { (1)=swelling present with loss of } \\
\text { saggital crest } \\
\text { (2\}=wide cerebral area }\end{array}$ \\
\hline $\begin{array}{l}\text { 40(74). CRANIUM: large dorsal } \\
\text { parietal bulges and frontoparietal } \\
\text { concavity }\end{array}$ & $(0)=$ absent & $(1)=$ present \\
\hline $\begin{array}{l}\text { 41(76). PREMAXILIAA: with } \\
\text { posterodorsal process in the mid- }\end{array}$ & $(0)=a b s e n t$ & $\begin{array}{l}\text { (1)=present, but does not protrude } \\
\text { vertically }\end{array}$ \\
\hline line, at the floor of the nasal fossa & & (2)=protrudes vertically \\
\hline $\begin{array}{l}42(77) \text {. MAXILLA: ridges prominent } \\
\text { and close to midline in ventral view }\end{array}$ & $(0)=a b s e n t$ & (1)=present \\
\hline 43(79). NAREAL OPENING: & $\begin{array}{l}(0)=\text { narrow (lateral } \\
\text { limits are vertical) }\end{array}$ & $\begin{array}{l}\text { (1)=wide (lateral limits are diagonal) } \\
\text { (2)=deep depressions laterally }\end{array}$ \\
\hline $\begin{array}{l}\text { 44(80). NAREAL OPENING: } \\
\text { lateral limits of }\end{array}$ & $\begin{array}{l}(0)=\text { do not extend } \\
\text { laterally }\end{array}$ & $\begin{array}{l}\text { (1)=extend laterally up to or } \\
\text { beyond width of rostrum }\end{array}$ \\
\hline $\begin{array}{l}\text { 45(82). PALATINE: spina nasalis } \\
\text { posterior above choanae }\end{array}$ & $(0)=a b s e n t$ & (1)=present \\
\hline 46(83). ORBIT: anterior border of & $\begin{array}{l}(0)=\text { situated above or } \\
\text { posterior to } \mathrm{M}^{1}\end{array}$ & (1)=forward of $M^{1}$ \\
\hline $\begin{array}{l}\text { 47(85). ORBIT: rim with angular } \\
\text { corners }\end{array}$ & $(0)=$ absent & (1) $=$ present \\
\hline $\begin{array}{l}\text { 48(88). CANALIS TEMPORALIS } \\
\text { (= squamosal-sinus canals) }\end{array}$ & $(0)=$ present & $(\mathbf{1})=a b s e n t$ \\
\hline $\begin{array}{l}\text { 49(89). INFRAORBITAL FORAMEN } \\
\text { duplication, on maxilla }\end{array}$ & $(0)=$ absent & $\begin{array}{l}\text { (1)=always present } \\
(2)=\text { sometimes present }\end{array}$ \\
\hline
\end{tabular}


Appendix 1 - continued.

\begin{tabular}{|c|c|c|}
\hline 1 & 2 & 3 \\
\hline $\begin{array}{l}\text { 50(92). FORAMEN OVALE and } \\
\text { FORAMEN LACERUM MEDIUM }\end{array}$ & $(0)=$ not confluent & (1)=confluent \\
\hline $\begin{array}{l}51(93) \text {. MANDIBULAR FORAMEN: } \\
\text { process at the anterior border }\end{array}$ & $(0)=$ absent & $(1)=$ present \\
\hline 52(94). MANDIBULAR SYMPHYSIS & $(0)=$ reduced symphysis & $\begin{array}{l}(1)=\text { long } \\
(2)=\text { short, spout-like }\end{array}$ \\
\hline $\begin{array}{l}\text { 53(96). MANDIBULAR ANGULAR } \\
\text { PROCESS: }\end{array}$ & $(0)=$ distinct & (1) $=$ reduced \\
\hline 54(98). BULLA (ectotympanic area) & $(0)=$ not enlarged & (1)=slightly enlarged posterolaterally \\
\hline $\begin{array}{l}\text { 55(99). STYLOHYOID: posterior } \\
\text { ramus }\end{array}$ & $(0)=$ absent & (1) = present \\
\hline $\begin{array}{l}56(100) \text {. STYLOHYOID: reduced } \\
\text { shelf at the base of the inferior ramus }\end{array}$ & $(0)=a b s e n t$ & (1) =present \\
\hline 57(101). STYLOHYOID; more gracile & $(0)=a b s e n t$ & (1)=present \\
\hline $\begin{array}{l}\text { 58(102). THORACIC VERTEBRAE: } \\
\text { number of }\end{array}$ & $(0)=20-21$ & $(1)=18-19,20$ \\
\hline $\begin{array}{l}\text { 59(106). HUMERUS: deep bicipital } \\
\text { groove and higher trochanter }\end{array}$ & $(0)=a b \operatorname{sen} t$ & $(1)=$ present \\
\hline $\begin{array}{l}60(110) \text {. ULNA: olecranon process } \\
\text { tilted medially and extends proxi- } \\
\text { mally beyond the trochlear notch }\end{array}$ & $(0)=a b s e n t$ & (1)=present \\
\hline $\begin{array}{l}\text { 61(111). CARPUS \& TARSUS: } \\
\text { low and wide, ie less 'cursorial' }\end{array}$ & $(0)=a b s e n t$ & $(1)=$ present \\
\hline $\begin{array}{l}62(112) \text {. MAGNUM: reduced lateral } \\
\text { bulging of the articular facet of scaphoid }\end{array}$ & $(0)=a b s e n t$ & (1) $=$ present \\
\hline $\begin{array}{l}\text { 63(113). PELVIS: well-delineated } \\
\text { distal obturator notch }\end{array}$ & $(0)=a b s e n t$ & (1)=present \\
\hline $\begin{array}{l}\text { 64(121). ASTRAGALUS protruding } \\
\text { tuberculum mediale }\end{array}$ & $(0)=a b s e n t$ & $\begin{array}{l}\text { (1)=present, large } \\
(2)=\text { present, reduced }\end{array}$ \\
\hline 65(131). Humeral condyles & $\begin{array}{l}(0)=\text { asymmetrical, ie } \\
\text { lateral condyle is larger }\end{array}$ & (1)=symmetrical \\
\hline $\begin{array}{l}66(134) \text {. Femoral head, fovea of (the } \\
\text { fovea houses the ligamentum teres) }\end{array}$ & $\begin{array}{l}(0)=\text { deep and cent- } \\
\text { rally placed }\end{array}$ & $\begin{array}{l}\text { (1)=displaced to posterior } \\
\text { surface of femoral head } \\
\text { (2)=fovea absent }\end{array}$ \\
\hline \multicolumn{3}{|c|}{ Part II - Characters after Kalb et al. (1996) } \\
\hline 67(K1). Cranium & $(0)=$ flattened & $(1)=$ rounded \\
\hline 68(K2). Occipital condyles & $(0)=$ protruding & $\{1\}=$ recessed \\
\hline 69(K6). Mandible width & $(0)=$ narrow & (1)=wide \\
\hline 70(K15). Curvilinear alignment of apices & $s(0)=$ absent & (1) $=$ present \\
\hline $\begin{array}{l}7 \mathrm{t}(\mathrm{K} 18) \text {. Posterior face of lophids } \\
\text { or lower plates (see notes K18a and }\end{array}$ & $(0)=$ very convex & (1)=shallow convex or ahsent \\
\hline $\begin{array}{l}\text { K18b in the caption to this appendix) } \\
72 \text { (K19). Posterior face of lophids } \\
\text { or lower plates (see note K18a) }\end{array}$ & $(0)=$ not concave & ( 1 l=shallow concave or very concave \\
\hline $\begin{array}{l}73(\mathrm{~K} 20) \text {. Posterior face of lophids } \\
\text { or lower plates (see note K18a) }\end{array}$ & $(0)=$ convex or mixed & (1)=concave \\
\hline
\end{tabular}


Appendix 1 - concluded.

\begin{tabular}{|c|c|c|}
\hline 1 & 2 & 3 \\
\hline $\begin{array}{l}\text { 74(K21). Anterior face of lophids } \\
\text { or lower plates (see note K18a) }\end{array}$ & $(0)=$ convex & (1)=concave or mixed \\
\hline $\begin{array}{l}75(\mathrm{~K} 22) \text {. Anterior face of lophids } \\
\text { or lower plates (see note K 18a) }\end{array}$ & $(0)=$ convex or mixed & (1)=concave \\
\hline $76(\mathrm{~K} 25-26)$. Median sulcus & $(0)=$ complete & (1)=incomplete \\
\hline 77(K27). Four apices (cones, conelets) & $(0)=$ present & (1)=five or more \\
\hline $\begin{array}{l}78(\mathrm{~K} 30) \text {. On } \mathrm{M}_{2} \text { and } \mathrm{M}_{3} \text {, posterior } \\
\text { pretrite conules/columns posteriorly }\end{array}$ & (0) $=$ present & (1) $=$ reduced/fused \\
\hline $\begin{array}{l}\text { 79(K31). On } \mathrm{M}^{3} \text {, posterior pretrite } \\
\text { conules/columns posteriorly }\end{array}$ & $(0)=a b s e n t$ & (1) $=$ present \\
\hline $\begin{array}{l}80(\mathrm{~K} 32) . \mathrm{On} \mathrm{M}_{2} \text { and } \mathrm{M}^{2} \text {, minimum } \\
\text { of plates }\end{array}$ & $(0)=$ three & $\begin{array}{l}(1)=\text { four } \\
(2)=\text { five } \\
(3)=\operatorname{six}\end{array}$ \\
\hline 81(K33). On $\mathrm{M}_{3}$, minimum of plates & $(0)=$ three & $\begin{array}{l}(1)=\text { five } \\
(2)=\text { six } \\
(3)=\text { seven } \\
(3)=\text { eight }\end{array}$ \\
\hline 82(K34). On $M^{3}$, minimum of plates & $(0)=$ three & $\begin{array}{l}(1)=\text { five } \\
(2)=\text { six } \\
(3)=\text { seven } \\
(3)=\text { nine }\end{array}$ \\
\hline \multicolumn{3}{|c|}{ Character after Maglio (1973, pp. 89-90) } \\
\hline $\begin{array}{l}83(\mathrm{~V}) \text {. Base of the transverse valley } \\
\text { between molar plates }\end{array}$ & $(0)=V$-shaped & (1) $=U$-shaped \\
\hline \multicolumn{3}{|c|}{ Part III - Characters after Tassy and Darlu's (1986) } \\
\hline 84(T\&D3). Alveoli of maxilla & $(0)=$ Jow & (1)=high \\
\hline $85(T \& D 4)$. Occlusal surface of $M^{3}$ & $(0)=$ horizontal & $(1)=$ convex \\
\hline $\begin{array}{l}86(T \& D 5) . \text { Mesoconelets in upper } \\
\text { molars }\end{array}$ & $(0)=$ of normal height & (1)=increase in height \\
\hline $\begin{array}{l}87(T \& D 6) . \text { Mesoconelets in lower } \\
\text { molars }\end{array}$ & $(0)=$ of normal height & (1)=increase in beight \\
\hline 88(T\&D9). Postglenoid fossa & $(0)=a b s e n t$ & (1)=present \\
\hline 89(T\&D 10). Mastoid groove & $(0)=a b s e n t$ & (1)=present \\
\hline $\begin{array}{l}\text { 90(T\&D13-4). Mandibular horizon- } \\
\text { tal ramus }\end{array}$ & $(0)_{=0}$ of normal height & (1)=increase in height \\
\hline 91(T\&D19). Molars & $(0)=$ wide & $(1)=$ narrow \\
\hline 92(T\&D20). Palate & $(0)=$ wide & (1)=narrow \\
\hline $\begin{array}{l}\text { 93(T\&D30). Pre-posttrite functional } \\
\text { dissymmetry }\end{array}$ & $(0)=$ present & (1)=absent ie erosion of loph(id)s \\
\hline $94(T \& D 31) . I_{2}$ & $(0)=$ present & (1)=absent \\
\hline $\begin{array}{l}\text { 95(T\&D32). Enamel on loph(id)s of } \\
\text { premolars and molars }\end{array}$ & $(0)=$ relatively thick & (1)=thinner \\
\hline
\end{tabular}


Appendix 2. Character matrix for 14 proboscidean taxa; cf Appendix 1 for list of characters and explanations.

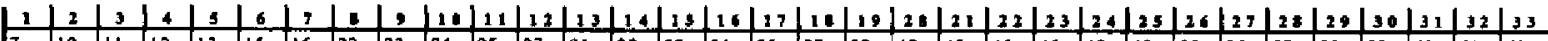

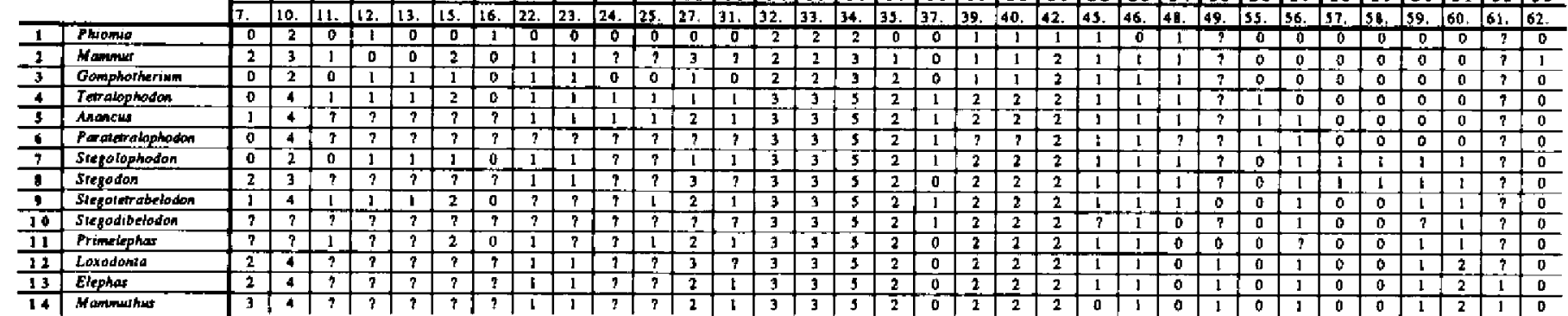
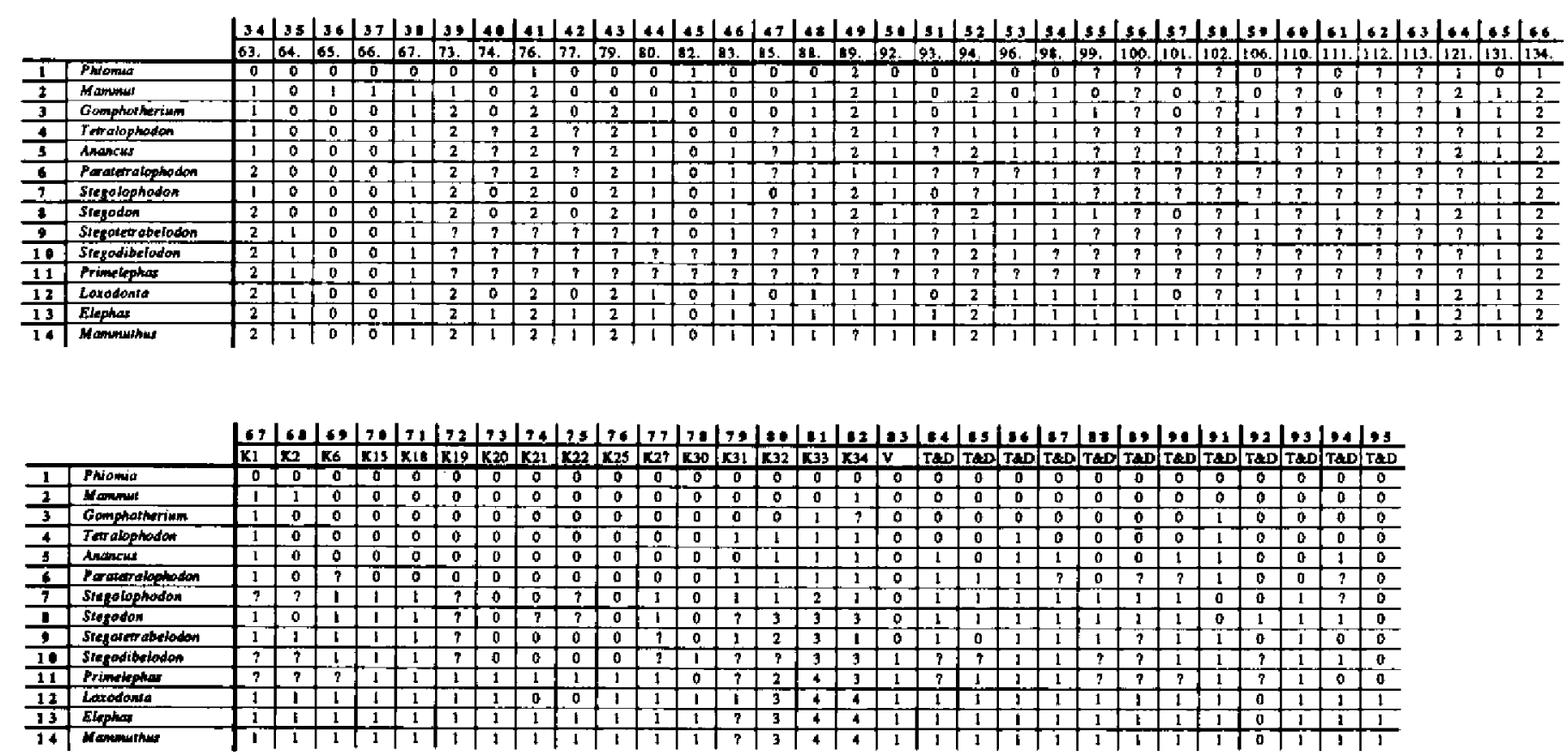
Appendix 3. Synapomorphies for clades in Figs. 1A and 1B.

Notes: *Appendix 1 provides a complete list of characters employed in this study, their primitive and derived conditions, and references consulted. Appendix 2 contains the data matrix upon which cladistic analyses were conducted. Sometimes the change of character state for a particular node is given, eg " $(12: 3 \rightarrow 4)^{\pi}$ means that, for this node, the synapomorphy for multistate character 12 is a change from state 3 to state 4 ; in binary characters the change is either from $0 \rightarrow 1$, or from $1 \rightarrow 0$ in the case of a reversal. To avoid confusion, in the listing below, sequential numbers of the characters are given first and these are followed by the original numbers. Nodes below are grouped according to those which appear on Figs $1 \mathrm{~A}$ and $1 \mathrm{~B}$, and in selected cases, notes are added. Results below are for ACCTRAN option in PAUP; two asterisks $\left({ }^{* *}\right)$ followed by a ${ }^{*}$ and a number refer to differences in number of character changes in DELTRAN option (ef caption to Fig. 1A and text for explanations). To simplify this appendix, details for these changes are not given here; they can be obtained from the senior author (some changes are given in Table 4).

"A fat arrow $(\rightarrow)$ means that the change occurs in all possible reconstructions (ie is unambiguous). A thin arrow $(\rightarrow)$ indicates that change occurs under some reconstructions but not others". Further, $\rightarrow$ indicates that the direction of change is undetermined and it occurs along branches connecting outgroups to ingroups. Whereas, $\rightarrow$ indicates that the direction of change is unambiguously within the ingroups (Swofford 1993, p. 120).

Node A - Elephantiformes, ie, Phiomia and all taxa to the right of it: Since Phiomia was employed the most plesiomorphic outgroup, no characters for the node A are available; they have been discussed by Tassy and Shoshani (1988), Tassy (1996) and Shoshani (1996).

Node B - Elephantimorpha, ie, Mammutidae and all taxa to the right of it: fifteen characters - * $8(22$; $\mathrm{Cl}=1.0): 0 \rightarrow 1,9(23 ; \mathrm{CI}=1.0): 0 \rightarrow 1,16(34 ; \mathrm{CI}=1.0): 2 \rightarrow 3,21(42 ; \mathrm{CI}=1.0): 1 \rightarrow 2,23(46 ; \mathrm{CI}=1.0): 0 \rightarrow 1$, $34(63 ; \mathrm{CI}=0.667): 0 \rightarrow 1,38(67 ; \mathrm{Cl}=1.0): 0 \rightarrow 1,41(76 ; \mathrm{CI}=1.0): 1 \rightarrow 2,48(88 ; \mathrm{CI}=1.0): 0 \rightarrow 1,50(92 ;$ $\mathrm{CI}=1.0): 0 \rightarrow 1,54(98 ; \mathrm{CI}=1.0): 0 \rightarrow 1,65(131=\mathrm{C} 40 ; \mathrm{CI}=1.0): 0 \rightarrow 1,66(134=\mathrm{C} 55 ; \mathrm{CI}=1.0): 1 \rightarrow 2,67(\mathrm{~K} 1$; $\mathrm{Cl}=1.0): 0 \rightarrow 1$, and $82(\mathrm{K34} ; \mathrm{CI}=0.75): 0 \rightarrow 1$. Note that the characters assigned for this node were coded as reversals in the output file of PAUP. This situation occurred because the characters for this node are distributed between Phiomia (the outgroup of Elephantoidea) and the clade Elephantoidea. We employed these characters as synapomorphies for the Elephantoidea based on the distribution of character states in Appendix 2. ${ }^{*}$ In the expression " $8(22 ; \mathrm{CI}=1.0), 0 \rightarrow 1^{\prime \prime}, 8$ is the sequential number, and 22 is the original number (see Appendix 1), and $\mathrm{CI}$ is the Consistency Index.

Node C - Elephantida ie, Gomphotherium and all taxa to the right of it: thirteen characters - 5(13; $\mathrm{CI}=1.0) ; 0 \rightarrow 1,12(27 ; \mathrm{CI}=0.5): 0 \rightarrow 1,17(35 ; \mathrm{CI}=1.0): 0 \rightarrow 2,39(73 ; \mathrm{CI}=1.0): 0 \rightarrow 2,43(79 ; \mathrm{CI}=1.0): 0 \rightarrow 2$, $44(80 ; \mathrm{CI}=1.0): 0 \rightarrow 1,45(82 ; \mathrm{CI}=1.0): 1 \rightarrow 0,53(96 ; \mathrm{CI}=1.0): 0 \rightarrow 1,55(99 ; \mathrm{CI}=1.0): 0 \rightarrow 1,59(106$ $\mathrm{CI}=1.0): 0 \rightarrow 1,61(111 ; \mathrm{CI}=1.0): 0 \rightarrow 1,81(\mathrm{~K} 33 ; \mathrm{CI}=1.0): 0 \rightarrow 1$, and $91(\mathrm{~T} \& \mathrm{D} 19, \mathrm{CI}=0.5): 0 \rightarrow 1$. Except for characters $12(27)$ and $91(T \& D 19)$ which have a consistency index (CI) of 0.5 each, the other 11 have CI of 1.0 . Character $45(82)$ is a reversal.

Node D - Unnamed, ie, Tetralophodon and all taxa to the right of it: sixteen **/thirteen characters $2(10 ; \mathrm{CI}=0.500): 2 \rightarrow 4,3(11 ; \mathrm{CI}=0.333): 0 \rightarrow 1,10(24 ; \mathrm{CI}=1.000): 0 \rightarrow 1,11(25 ; \mathrm{CI}=1.000): 0 \rightarrow 1,13(31 ;$ $\mathrm{CI}=1.000): 0 \rightarrow 1,14(32 ; \mathrm{CI}=1.000): 2 \rightarrow 3,15(33 ; \mathrm{CI}=1.000): 2 \rightarrow 3,16(34 ; \mathrm{CI}=1.000): 3 \rightarrow 5,18(37 ;$ $\mathrm{Cl}=0.333): 0 \rightarrow 1,19(39 ; \mathrm{Cl}=1.000): 1 \rightarrow 2,20(40 ; \mathrm{Cl}=1.000): 1 \rightarrow 2,26(55 ; \mathrm{CI}=0.500) ; 0 \rightarrow 1$, $64(121=\mathrm{C} 64 ; \mathrm{CI}=0.500): 1 \rightarrow 2,79(\mathrm{~K} 31 ; \mathrm{CI}=0.500): 0 \rightarrow 1,80(\mathrm{~K} 32 ; \mathrm{CI}=0.750): 0 \rightarrow 1,86(\mathrm{~T} \& \mathrm{D} 5 ;$ $\mathrm{CI}=1.000): 0 \rightarrow 1$. Nine of these sixteen characters have a $\mathrm{CI}$ of 1.0 , four with $\mathrm{CI}$ of 0.5 , one with $\mathrm{CI}$ of 0.75 , and two with $\mathrm{CI}$ of 0.3 .

Overall, this clade is based on solid characters (those with CI of 1.0). Similar results were observed by Tassy (1990, 1996) and Kalb et al. (1996). These findings corroborate the hypothesis that Stegodontidae is more closely related to gomphotheres and elephantids than to mammutids (Maglio 1973, Tobien 1988).

Node E - Unnamed, ie, Anancus and all taxa to the right of it: eight characters - $12(27 ; \mathrm{CI}=0.500): 1$ $\rightarrow 2,27(56 ; \mathrm{CI}=1.000): 0 \rightarrow 1,46(83 ; \mathrm{CI}=1.000): 0 \rightarrow 1,52(94 ; \mathrm{CI}=0.333): 1 \rightarrow 2,84(\mathrm{~T} \& \mathrm{D} 3 ; \mathrm{CI}=1.000): 0$ $\rightarrow 1,87(\mathrm{~T} \& \mathrm{D} 6 ; \mathrm{Cl}=1.000): 0 \rightarrow \mathrm{I}, 90(\mathrm{~T} \& \mathrm{D} 13-4 ; \mathrm{CI}=1.000): 0 \rightarrow \mathrm{I}, 94(\mathrm{~T} \& \mathrm{D} 31 ; \mathrm{CI}=0.333): 0 \rightarrow 1$. Five characters are with $\mathrm{Cl}$ of 1.0 , one with $\mathrm{CI}$ of 0.5 , and two with $\mathrm{CI}$ of 0.3 . 
Node F - Unnamed, ie, Paratetralophodon and all taxa to the right of it: five **/three characters 34(63; $\mathrm{CI}=0.667): 1 \rightarrow 2,49(89 ; \mathrm{Cl}=0.500): 2 \rightarrow 1,69(\mathrm{~K} 6 ; \mathrm{CI}=0.500) ; 0 \rightarrow 1,85(\mathrm{~T} \& \mathrm{D} 4 ; \mathrm{CI}=0.500): 0 \rightarrow 1$, 89(T\&D10; CI=1.000):0 $\rightarrow 1$.

Node G - Elephantoidea including and all taxa to the right of it (ie, Stegodontidae and Elephantidae): eleven characters $-1(7 ; \mathrm{CI}=0.500): 0 \rightarrow 2,26(55 ; \mathrm{Cl}=0.500): 1 \rightarrow 0,30\langle 59 ; \mathrm{CI}=1.000): 0 \rightarrow 1,31(60 ;$ $\mathrm{CI}=1.000): 0 \rightarrow 1,70(\mathrm{~K} 15 ; \mathrm{CI}=1.000) ; 0 \rightarrow 1,71(\mathrm{~K} 18 ; \mathrm{CI}=1.000): 0 \rightarrow 1,72(\mathrm{~K} 19 ; \mathrm{CI}=1.000): 0 \rightarrow 1$, $77(\mathrm{~K} 27 ; \mathrm{CI}=1.000): 0 \rightarrow 1,81(\mathrm{~K} 33 ; \mathrm{CI}=1.000): 1 \rightarrow 3,88(\mathrm{~T} \& \mathrm{D} 9 ; \mathrm{CI}=1.000): 0 \rightarrow 1,93(\mathrm{~T} \& \mathrm{D} 30 ;$ $\mathrm{CI}=1,000): 0 \rightarrow 1$.

Character state 0 of number 26(55; absence of trefoils in molars) is a reversal of the primitive condition. Characters 30(59; adaxial and abaxial cones and their conelets are of about equal size) and 31(60; molars with laminae) are good characters with CI of 1.0 . Seven other characters with $\mathrm{CI}=1.0$ are given, five of Kalb et al. (1996) and two of Tassy and Darlu (1986).

Node G.1 - Family Stegodontidae: eight characters $-2(10 ; \mathrm{CI}=0.500): 4 \rightarrow 2,3(11 ; \mathrm{CI}=0.333): 1 \rightarrow 0$, $6(15 ; \mathrm{CI}=0.667): 2 \rightarrow 1,12(27 ; \mathrm{CI}=0.500): 2 \rightarrow 1,28(57 ; \mathrm{CI}=1.000): 0 \rightarrow 1,29(58 ; \mathrm{CI}=1.000): 0 \rightarrow 1,49489 ;$ $\mathrm{CI}=0.500): 1 \rightarrow 2,91(\mathrm{~T} \& \mathrm{D} 19 ; \mathrm{CI}=0.500): 1 \rightarrow 0$.

Of these eight characters, numbers 28(57; accentuated brachyodont molars) and 29(58; fusion of anterior pretrite central conule and adaxial conelets) - appear to be very good synapomorphies for the Stegodontidae.

Grouping of Stegodon and Stegolophodon in Stegodontidae, although strongly defended by Saegusa (1996), and also by Shoshani (1996) and Tassy (1996), is not strongly supported, because with two evolutionary steps, Stegodon and Stegolophodon can be separated and Stegodon will be a sister taxon to Elephantidae clade (Test no. 2 in Table 2)

Node $\mathrm{H}$ - Family Elephantidae and all taxa to the right of it: three **/five characters - 35(64; $\mathrm{CI}=1.000): 0 \rightarrow 1,68(\mathrm{K2} ; \mathrm{CI}=0.500): 0 \rightarrow 1,80(\mathrm{~K} 32 ; \mathrm{CI}=0.750): 1 \rightarrow 2$.

Among these three characters, number 35(64; hypsodont molars) appears to be the best. Characters 68 (K2; occipital condyles recessed) and $80\left(\mathrm{~K} 32 ; \mathrm{M}_{2}\right.$ and $\mathrm{M}^{2}$ with minimum five plates), although with weaker CI, are relatively good characters. The content of the Elephantidae was discussed by Maglio (1973), Tassy and Shoshani (1988), Kalb et al. (1996), Tassy (1996) and Todd and Roth (1996).

Node 1 - Unnamed, ie, Stegodibelodon and all taxa to the right of it; four $* * /$ three characters $-24(48$; $\mathrm{Cl}=1.000): 1 \rightarrow 0,78(\mathrm{K3} ; \mathrm{CI}=0.500): 0 \rightarrow 1,82(\mathrm{~K} 34 ; \mathrm{Cl}=0.750): 1 \rightarrow 3,83(\mathrm{~V} ; \mathrm{CI}=1.000): 0 \rightarrow 1$ Character $24(48)$ is a reversal.

Node $J$ - Unnamed, ie, Primelephas and all taxa to the right of it: six **/five characters - 18(37; $\mathrm{CI}=0.333): 1 \rightarrow 0,73(\mathrm{~K} 20 ; \mathrm{CI}=1.000): 0 \rightarrow 1,74(\mathrm{~K} 21 ; \mathrm{CI}=0.500): 0 \rightarrow 1,75(\mathrm{~K} 22 ; \mathrm{CI}=0.500): 0 \rightarrow 1$, $76(\mathrm{~K} 25 ; \mathrm{CI}=1.000): 0 \rightarrow 1,81(\mathrm{~K} 33 ; \mathrm{CI}=1,000): 3 \rightarrow 4$. Character $18(37)$ is a reversal

Node K - Subfamily Elephantinae and all taxa to the right of it: five characters $-25(49 ; \mathrm{Cl}=1,000): 0$ $\rightarrow 1,31(60 ; \mathrm{CI}=1.000): 1 \rightarrow 2,80(\mathrm{~K} 32 ; \mathrm{Cl}=0.750): 2 \rightarrow 3,82(\mathrm{~K} 34 ; \mathrm{Cl}=0.750): 3 \rightarrow 4,95(\mathrm{~T} \& \mathrm{D} 32 ;$ $\mathrm{CI}=1,000) ; 0 \rightarrow 1$.

Node L - Elephas and Mammuthus: five **/eight characters -- 40(74; CI=1.000):0 $\rightarrow$ 1, 42(77; $\mathrm{CI}=1.000): 0 \rightarrow 1,47(85 ; \mathrm{CI}=1.000): 0 \rightarrow 1,51(93 ; \mathrm{CI}=1.000): 0 \rightarrow 1,57(101 ; \mathrm{CI}=1.000): 0 \rightarrow 1$.

Appendix 4. Proboscidean samples used in this study (after Yang et al. 1997b). (1) The nickname or identification of the animal is given in parentheses. (2) Museum abbreviations: WSUMNH - Wayne State University Museum of Natural History (Detroit, Michigan, USA), MNHN - Museum National d'Histoire Naturelle (Paris, France), BMNFI - British Museum of Natura] History (London, England, New Name: Natural History Museum), AMNH - American Museum of Natural History (New York City, New York, USA), OCC - Oakland Community College, Highland Lake Campus (Union Lake, Michigan, USA). (3) A or a - Proteinase K organic extraction method (Cooper 1994, Hagelberg 1994), 
B or b - Glass bead extraction method (Höss and Pääbo 1993, Cano and Poinar 1993), C or c- CTAB extraction method (Doyle and Doyle 1987, Golenberg 1994). Capital letter indicates success in obtaining amplifiable endogeneous DNA; whereas small letter represents failure. (4) Other references are in Yang et al. (1997b). (5) The putative intergeneric hybrid between the two modern elephants, Loxodonta and Elephas, had an Asian elephant mother. The male elephant calf died ten days after his birth on July 11, 1978 at the Chester Zoo in England. The preserved specimen was prepared by a private company for the museum and the chemical preservatives used to treat the specimen were not revealed.

\begin{tabular}{|c|c|c|c|c|c|}
\hline $\begin{array}{l}\text { Taxon (1) } \\
\text { sample number } \\
\text { and name }\end{array}$ & $\begin{array}{l}\text { Nature } \\
\text { of samples }\end{array}$ & $\begin{array}{c}\text { Sample } \\
\text { storage (2) } \\
\text { and label } \\
\text { number in the } \\
\text { museum }\end{array}$ & $\begin{array}{c}\text { Age } \\
\text { (radiocarbon } \\
\text { date in years } \\
\text { before present) } \\
\text { and origin } \\
\text { of sample }\end{array}$ & $\begin{array}{l}\text { Extraction } \\
\text { methods } \\
\text { tested } \\
\text { (3) }\end{array}$ & n References (4) \\
\hline $\begin{array}{l}\text { EL\#1. Elephas } \\
\text { maximus (Iki) }\end{array}$ & $\begin{array}{l}\text { Skin preserved } \\
\text { in salt. }\end{array}$ & WSUMNH & (1), died in 1980 & a, B, C & $\begin{array}{l}\text { Shoshani et al. } \\
1982\end{array}$ \\
\hline $\begin{array}{l}\text { EL\#2. Mammuthus } \\
\text { primigenius } \\
\text { (Lyakhovskiy } \\
\text { mammoth) }\end{array}$ & $\begin{array}{l}\text { Air dried skin } \\
\text { from frozen } \\
\text { specimen }\end{array}$ & MNHN & $\begin{array}{l}(>46,000) \\
\text { Lyakhovskiy } \\
\text { Island, Siberian } \\
\text { Arctic, Russia }\end{array}$ & $\mathrm{a}, \mathrm{b}, \mathrm{C}$ & $\begin{array}{l}\text { J. Shoshani et al } \\
\text { unpubl. data }\end{array}$ \\
\hline $\begin{array}{l}\text { EL\#3. A hybrid } \\
\text { between the two } \\
\text { extant elephant } \\
\text { genera }(4,5) \text { (Motty) }\end{array}$ & $\begin{array}{l}\text { Skin preserved } \\
\text { in unknown } \\
\text { chemical } \\
\text { preservatives }\end{array}$ & BMNH & $(16)$, died in 1978 & $\mathrm{a}, \mathrm{B}, \mathrm{C}$ & $\begin{array}{r}\text { Lowenstein and } \\
\text { Shoshani } 1996\end{array}$ \\
\hline $\begin{array}{l}\text { EL\#4, Loxodonta } \\
\text { africana (Mtoto) }\end{array}$ & $\begin{array}{l}\text { Skin preserved } \\
\text { in salt }\end{array}$ & $\begin{array}{l}\text { Brookfield Zno } \\
\text { Brookfield, } \\
\text { Illinois, USA }\end{array}$ & (2), fied in 1992 & $A, B, C$ & $\begin{array}{l}\text { J. Shoshani, } \\
\text { unpubl. data }\end{array}$ \\
\hline $\begin{array}{c}\text { EL\#5. Elephas } \\
\text { maximus (Iki) }\end{array}$ & $\begin{array}{l}\text { Air dried } \\
\text { muscle }\end{array}$ & WSUMNH & (14), died in 1980 & $\mathrm{a}, \mathrm{B}, \mathrm{C}$ & $\begin{array}{l}\text { Shoshani et al. } \\
1982\end{array}$ \\
\hline $\begin{array}{l}\text { EL\#6. Mammut } \\
\text { americanum } \\
\text { (Shelton) }\end{array}$ & $\begin{array}{l}\text { Cranial } \\
\text { fragment }\end{array}$ & WSUMNH & $\begin{array}{l}(12,320), \\
\text { Oakland County, } \\
\text { Michigan, LSA }\end{array}$ & $a, b, c$ & $\begin{array}{l}\text { Shoshani et al. } \\
1989\end{array}$ \\
\hline $\begin{array}{l}\text { El_ 19. Mammuthus } \\
\text { primigenius } \\
\text { (Alaska mammoth) }\end{array}$ & $\begin{array}{l}\text { Cranial } \\
\text { fragment }\end{array}$ & $\begin{array}{l}\text { AMNH } \\
\text { \#FAM A } \\
2001-D\end{array}$ & $\begin{array}{l}\text { (20,000), Cripple } \\
\text { (Creek, } \\
\text { Alaska, USA }\end{array}$ & $A, b, c$ & $\begin{array}{l}\text { J. P. Alexander, } \\
\text { pers. comm. } \\
1994\end{array}$ \\
\hline $\begin{array}{l}\text { EL\#23. Mammut } \\
\text { americanum } \\
\text { (Elmer) }\end{array}$ & Rib fragment & $\mathrm{OCC}$ & $\begin{array}{l}(10,200) \\
\text { Oakland County, } \\
\text { Michigan, USA }\end{array}$ & a, b, C & $\begin{array}{l}\text { Shoshani et al. } \\
\text { 1985a }\end{array}$ \\
\hline $\begin{array}{l}\text { EL\#32. Mammut } \\
\text { americanum } \\
\text { (Elmer) }\end{array}$ & Rib fragment & OCC & $\begin{array}{l}(10,200) \\
\text { Oakland County, } \\
\text { Michigan, USA }\end{array}$ & $a, b, c$ & $\begin{array}{l}\text { Shoshani et al. } \\
1985 \mathrm{a}\end{array}$ \\
\hline $\begin{array}{l}\text { EL\#29. Mammut } \\
\text { americanum } \\
\text { (not named) }\end{array}$ & $\begin{array}{l}\text { Cranial } \\
\text { fragment }\end{array}$ & WSUMNH & $\begin{array}{l}\text { Late Pleistocene, } \\
\text { radiocarbon date } \\
\text { is not available }\end{array}$ & $a, b, c$ & $\begin{array}{l}\text { J. Shoshani, } \\
\text { unpubl. data }\end{array}$ \\
\hline
\end{tabular}

